\title{
Testicular dysgenesis syndrome and phthalate exposure: \\ A review of literature
}

\author{
Pınar Erkekoglu ${ }^{1,2, *}$, Aylin Balcı Özyurt ${ }^{1}$, Anıl Yirün ${ }^{1,3}$, \\ Deniz Arca Çakır ${ }^{2}$
}

\author{
${ }^{1}$ Hacettepe University Faculty of Pharmacy \\ Department of Toxicology Sihhiye 06100 Ankara, Turkey \\ ${ }^{2}$ Hacettepe Vaccine Institute Department of Vaccine Technology \\ Sihhiye 06100 Ankara, Turkey \\ ${ }^{3}$ Çukurova Faculty of Pharmacy, Department of Toxicology Adana, Turkey
}

*Corresponding author: P1nar Erkekoglu, E-mail:erkekp@hacettepe.edu.tr

\begin{abstract}
Endocrine disruptors are chemicals that interfere with the body's endocrine system and cause adverse effects in biological systems. Phthalates are a group of man-made chemicals which are mainly used as plasticizers and classified as endocrine disruptors. They are also used in cosmetic and personal care products as color or smell fixators. Moreover, phthalates are present in inks, adhesives, sealants, automobile parts, tools, toys, carpets, medical tubing and blood storage bags, and food packages. Pathological condition known as "testicular dysgenesis syndrome" (TDS) or "phthalate syndrome" is usually linked to phthalate exposure and is coined to describe the rise in alterations in reproductive health in men, such as reduced semen quality (decrease in sperm counts, sperm motility and increase in abnormal sperms), hypospadias, cryptorchidism, reduced anogenital distance and early-life testicular cancer. Phthalates are suggested to cause direct effect on gonadal and non-gonadal tissues, impair the differentiation and morphogenesis of seminiferous tubules and accessory sex organs and testicular cells (both Sertoli and Leydig cells), alter estradiol and/or testosterone levels, decrease insulin-like 3 (INSL3) peptide production, impair spermatogenesis and lead to epigenetic alterations, all of which may lead to TDS. This review will mainly focus on phthalates as causes of TDS and their mechanisms of action.
\end{abstract}

Keywords: testicular dysgenesis syndrome, endocrine disruptor chemicals, phthalate, male reproductive system defects

doi.org/10.5937/arhfarm71-34438 


\section{Introduction}

Since Silent Spring was published on September $27^{\text {th }}, 1962$, awareness of the public to the exposure to environmental chemicals has been on the rise. Silent Spring, written by Rachel Carlson, mainly focused on the environmental toxicity caused by the high usage of different kinds of pesticides. Chemical companies met the book with fierce opposition. However, it brought numerous changes to the United States' national pesticide policy and a nationwide ban on the agricultural uses of dichlorodiphenyltrichloroethane, commonly known as DDT, in 1972. Moreover, this environmental movement provided the establishment of the U.S. Environmental Protection Agency (US EPA) (1-4). The Stockholm Convention on Persistent Organic Pollutants banned most uses of DDT and other organochlorine pesticides, except its use as an anti-malarial agent (5). DDT is now a well-known endocrine disruptor $(6,7)$. Although studies have suggested that it is not genotoxic, DDT is considered to be possibly carcinogenic to humans by the International Agency for Research on Cancer (IARC) (8,9). Its main metabolite dichlorodiphenyldichloroethylene (DDE) is considered to be a potent androgen antagonist. Another metabolite, o, p'-DDT, has weak estrogenic activity (10). In utero DDT exposure may lead to a higher risk of breast cancer (11).

Nowadays, life is inevitable without plastics. In order to soften plastics, phthalates are used abundantly and they are highly present in the environment. Other than their use in plastics, they are used in cosmetics and personal care products and as solvents in the industry. They are well-known endocrine disruptors, and they are suggested to be one of the causes of the decrease in fertility throughout the world.

This review will mainly focus on phthalates as causes of testicular dysgenesis syndrome (TDS) and their mechanisms of action. We will review the literature on mechanisms of endocrine disruption, phthalates, their uses and exposure routes, how phthalates may cause TDS and the in vitro, in vivo and human studies that suggest a link between TDS and phthalate exposure.

\section{Endocrine disruptors}

Over the last three decades, several studies have suggested that many natural and man-made chemicals might interfere with the body's endocrine system and cause adverse effects in humans, animals, and wildlife. Scientists often refer to these chemicals as "endocrine disruptors" (12). EPA defines endocrine disrupting chemicals as "chemicals that interfere with the normal functions of the endocrine system and lead to problems with reproduction (i.e. egg and sperm production) and development (i.e. healthy fetal growth) in both humans and wildlife" (13). Today, the phrase "endocrine disruption" is seemingly linked with terms like "environmental estrogens", "environmental anti-androgens", "male infertility" and "falling sperm counts". Although these links help the public understand the effects of endocrine disruption better, they are simply a narrow view of the way in which this phenomenon affects the endocrine system, since its effects include but are not limited to these. Other than effects on gonads and reproduction, endocrine-disrupting 
effects also include "effects on other hormone-producing organs/glands like thyroid, parathyroid, anterior and posterior pituitary, pancreas, adrenals and pineal" (14).

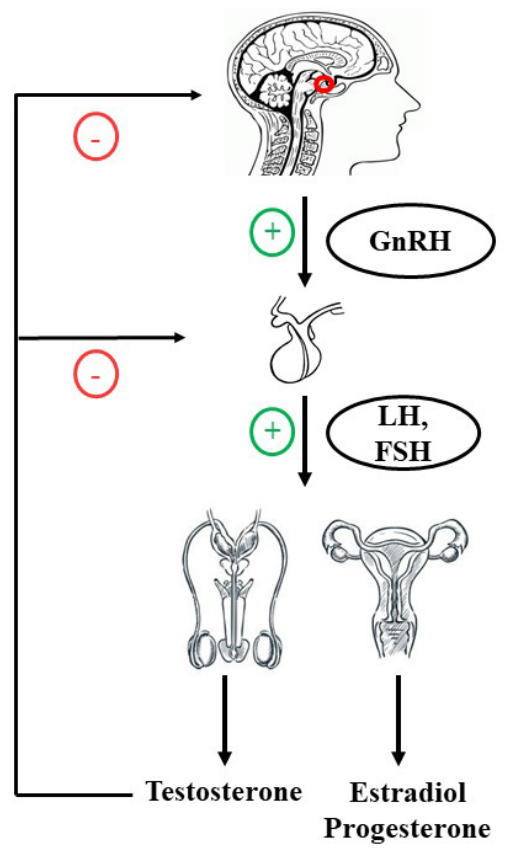

Figure 1. Shematic representation HPG axis HPG: Hypothalamic-Pituitary-Gonad; GnRH: Gonadotrophin-Releasing Hormone; LH: Luteinizing hormone; FSH: Follicle stimulating hormone

Slika 1. Shematski prikaz HPG ose HPG: Hipotalamusno-hipofizno-gonadalna osovina; GnRH: gonadotropin-oslobađajući hormon; LH: luteinizirajući hormon; FSH: folikulostimulirajući hormon

The endocrine system is one of the most complex systems in human body, with many interconnecting and interacting axes. The mature reproductive system is mainly regulated by the hypothalamus-pituitary-gonad (HPG) axis (Figure 1), which functions as a classical negative feedback system. This axis mainly includes the gonadotrophinreleasing hormone (GnRH) neurons in the hypothalamus, which release $\mathrm{GnRH}$ into the portal blood supply. GnRH's main function is to stimulate gonadotrophin release, namely luteinizing hormone (LH) and follicle-stimulating hormone (FSH), from the gonadotroph cells localized in the pituitary gland. After LH and FSH are released into systemic circulation, they affect the endocrine active cells of the testis or ovary. Testes have different cell types: under the effect of LH, Leydig cells secrete testosterone and estradiol. On the other hand, FSH mainly affects the Sertoli cells that secrete inhibin B and create a microenvironment for sperm cells to survive. Later, pituitary and hypothalamus receive these gonadal signals by a feedback mechanism and they can regulate the release of GnRH and the gonadotrophins (14). Several endocrine-disrupting chemicals can potentially affect the HPG axis at any level. However, data from different studies mainly support for the idea that these chemicals affect the development and programming of the 
axis during fetal life, and in utero exposure can be the most sensitive period in which environmental chemicals, including endocrine disruptors, can alter the homeostatic mechanisms of the endocrine system permanently (14).

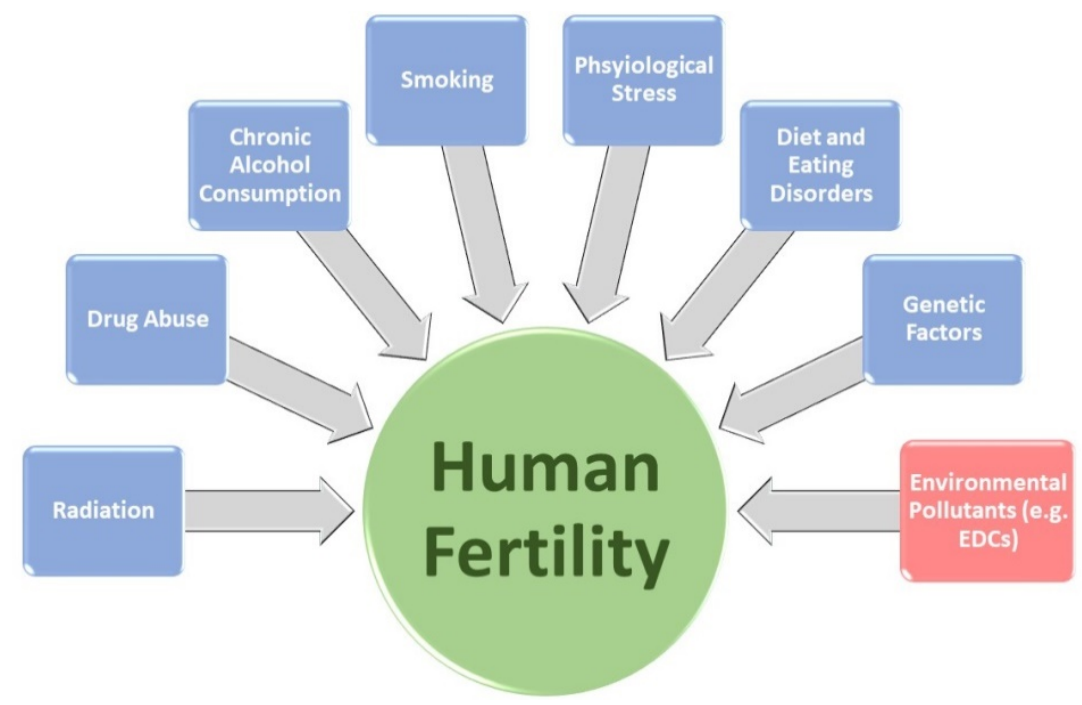

Figure 2. Parameters that affect human fertility EDC: Endocrine disrupting chemicals

Slika 2. Parametri koji utiču na plodnost ljudi EDC: endokrini ometači

Although lifestyle (diet, eating disorder, smoking and/or alcohol consumption, drug abuse, physiological stress) is considered to be the main factor that affects human fertility, literature suggests that endocrine disruptors may also affect reproduction, particularly male, and cause pathologies if the exposure to these chemicals happens in early life (Figure 2) (15). On the other hand, limiting the effects of endocrine disruptors to their "estrogenic mode of action" is too simplistic. Many studies currently suggest that these chemicals can act as estrogens, anti-estrogens, androgens and antiandrogens. Moreover, they can inhibit or induce steroidogenic enzymes, increase or decrease protein expression of certain hormones, they can be inhibitors of thyroid hormones and/or their receptors, or they can affect the synthesis or secretion of pancreatic or adrenal hormones. The current opinion of many scientists is that chemicals that interfere with the action and/or production of steroids may be of more concern to reproductive health. On the other hand, in the last decade, the phenomenon of neuroendocrine disruption by endocrine disruptors is well defined and now it is suggested that many endocrine-disrupting chemicals may also lead to alterations in the HPG or hypothalamus-pituitary-thyroid (HPT) axis (Figure 3 ). On the other hand, some of these chemicals can also cause immunotoxicity (16). 


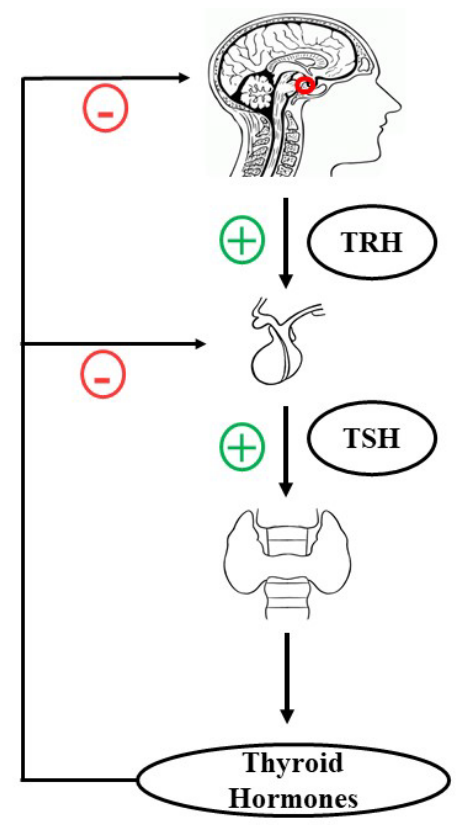

Figure 3. Shematic representation of HPT axis HPT: hypothalamic-pituitary-thyroid; TRH: thyrotropin-releasing hormone; TSH: thyroid-stimulating hormone

Slika 3. Shemataski prikaz HPT osa HPT: Hipotalamusno-hipofizno-tiroidna osovina; TRH: tireotropin oslobađajući hormon; TSH: tireoidni stimulirajući hormon

\section{Testicular dysgenesis syndrome}

In the last decades, reproductive disorders in males have frequently been reported by serious reports and epidemiological studies. From different parts of the globe, several researchers are now investigating the effects of endocrine disruption on male reproductive system. Studies conducted by researchers from different disciplines mainly point out that there is a decline in male fertility. Moreover, an increase has been observed in congenital reproductive tract anomalies (such as cryptorchidism, hypospadias and reduced anogenital distance (AGD)) and testicular cancers (between ages 35-45).

The term testicular dysgenesis syndrome (TDS) mainly describes "the rise in alterations in reproductive health in men, such as reduced semen quality (decrease in sperm counts and sperm motility as well as increase in abnormal sperms), hypospadias, cryptorchidism and early-life testicular cancer" $(17,18)$. The TDS hypothesis proposes that a proportion of these pathologies may be symptoms of one underlying developmental disease called TDS, which is most likely a result of disturbed gonadal development in the embryo (19). Although lifestyle, genetics and geographical regions are influential factors, they may not be sufficient to fully explain the increase in TDS. Scientists today suggest 
that higher exposure to chemicals in large cities or industrialized areas seem to be effective in this rise. The pathogenesis of TDS is shown schematically in Figure 4.

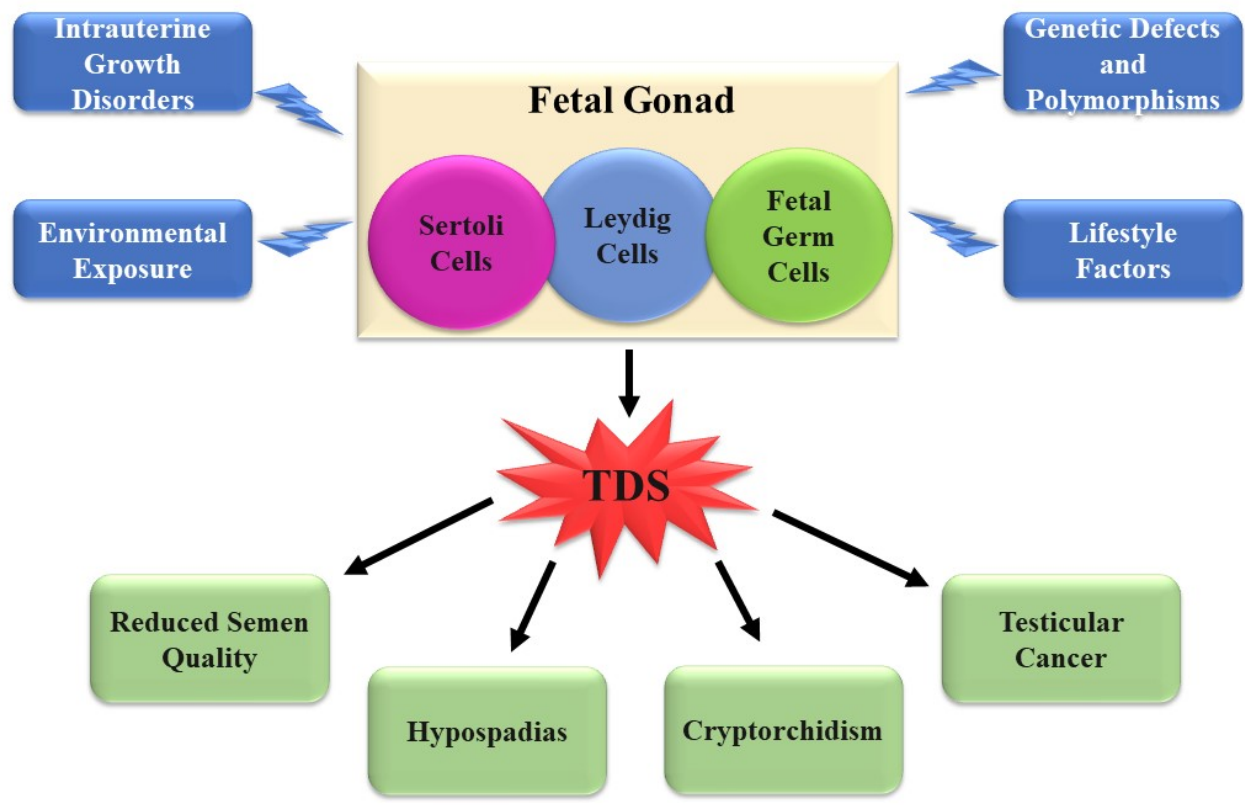

Figure 4. Pathogenesis of testicular dysgenesis syndrome TDS: Testicular dysgenesis syndrome

Slika 4. Patogeneza sindroma testikularne disgeneze TDS: sindrom testikularne disgeneze

Comparing two Nordic countries, Finland and Denmark, can be an interesting example. Finland is the country with the lowest risk of testicular cancer in Europe, whereas the incidence of testicular cancer in Denmark is the highest in Europe. Moreover, Danish men have a lower sperm count in comparison to Finnish men, and Danish boys have a higher prevalence of cryptorchidism and hypospadias when compared to Finnish newborn boys $(20,21)$. However, it is observed that reproductive health has deteriorated in Finland in recent years. The testis cancer incidence is increasing, and sperm concentrations are decreasing due to higher endocrine-disrupting chemical exposure compared to recent decades (22). The lower rates of TDS and early-life testicular cancer can be based on their good genetic background for Finnish boys and men. However, the increasing rates can be dependent on higher exposure to endocrine disruptors today. What is even more interesting is that Finnish men, who migrated to Sweden in their early twenties, follow the Finnish incidence of testis cancer, whereas their sons, who were conceived and born in Sweden, follow the Swedish incidence rate (23). This finding clearly suggests that the hypothesis "in utero high endocrine disruptor exposure may be an important factor in TDS's etiology". 
The scientific evidence that TDS may be caused by a marked decrease in the production of testosterone by the fetal testis is mainly dependent on many studies on phthalates using rodents. Indeed, all of the TDS phenotypes other than testicular cancer were suggested to be in association with gestational exposure of rodents, particularly rats, to high doses (500-750 mg phthalate/kg body weight) of phthalates. These exposures mainly caused significant declines in the production of testosterone by fetal testis. It should also be emphasized that gestational exposure of rats to estradiol or diethylstilbestrol (DES) results in similar alterations, such as alterations in the testis and accessory sex organs and cryptorchidism, caused by phthalates $(24,25)$. The similarity between estradiol/DES exposure and phthalate exposure may be dependent on the androgen-estrogen imbalance, since all of these chemicals may cause such effects during fetal development (26).

There have been several epidemiological studies conducted on the phthalate exposure of the general populations. A study conducted by Centers for Disease Control and Prevention (CDC) measured the urinary levels of 13 phthalate metabolites of over 2600 people (age: 6 years and older) who took part in the National Health and Nutrition Examination Survey (NHANES) in 2003-2004. CDC published these findings in the Fourth National Report on Human Exposure to Environmental Chemicals. This study revealed that the general American population had detectable levels of many phthalate metabolites. Adult women had higher urinary levels of phthalate metabolites compared to men, most probably due to their higher use of cosmetics and/or personal care products like body washes, shampoos, soaps and make-up products. Non-Hispanic Blacks had higher urinary phthalate and their metabolite levels in comparison to Non-Hispanic Whites. The results indicated that the general American population had a widespread exposure to many phthalate derivatives (27).

\section{Phthalates and exposure routes}

Life is inconceivable without plastics. Phthalates are (di-alkyl or alkyl-aryl) diesters of phthalic acid. These derivatives are used as plasticizers in order to impart flexibility and durability to plastic products $(28,29)$. Some phthalates in polyvinyl chloride (PVC) plastics are used to make products such as medical tubing, garden hoses and plastic packaging. Some phthalates are used to help dissolve other materials. Phthalates are also present in hundreds of products, such as vinyl flooring, carpets and lubricating oils (30). In addition, they are used as a matrix in cosmetic products and personal-care products (soaps, shampoos, hair sprays, nail polish, etc.) in order to protect the color or the smell for longer periods. Moreover, phthalates are present in medical tubing, packaging films, inks, adhesives, sealants, plastics of personal care products (i.e. toothbrushes), automobile parts, tools, toys, carpet-back coating and blood storage bags, floor tile, wire, cables, and food packaging $(28,31,32)$.

General population is orally exposed to phthalates by foods, which have contacted packages that contain different phthalate derivatives. They are also present in drinking water and ambient air at very low amounts $(28,29)$. In workplaces that produce or use 
phthalates, exposure can occur from breathing phthalate particles in the air. On the other hand, the general population can be exposed to phthalates by inhaling the released phthalates from packages, floorings, PVC windows and/or carpets (27). Exposure routes to phthalates are shown in Figure 5.

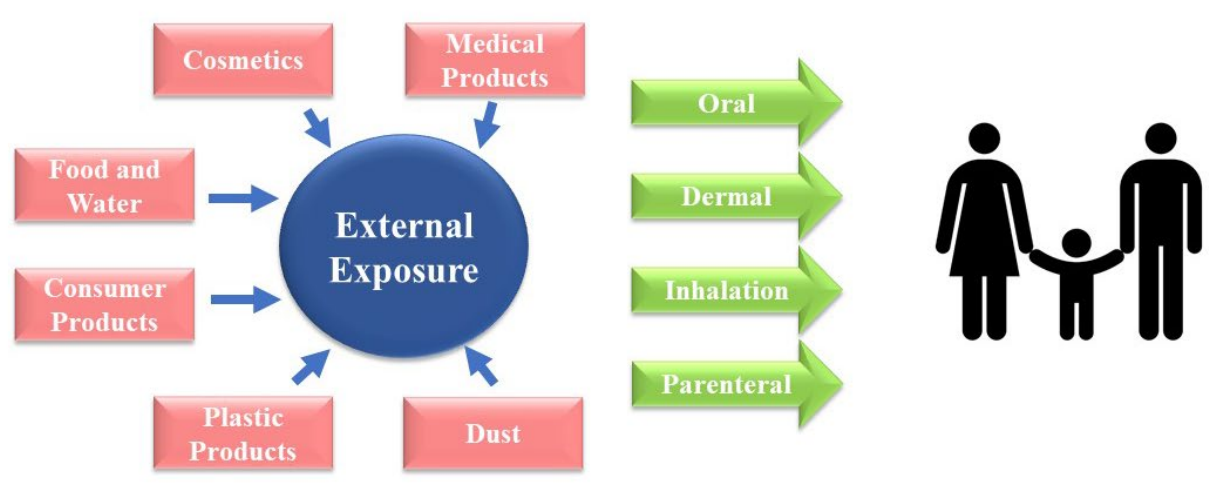

Figure 5. Exposure routes of phthalates

Slika 5. Putevi izloženosti ftalatima

Babies and young children have the habit of touching many things and then put their hands in their mouths. Because of this significant behavior, phthalate particles present in the dust may pose a greater risk for children than for adults. On the other hand, they put their toys in the mouth and therefore, phthalate-containing toys can be an exposure route for children (27). Humans can also be exposed to phthalates through medical procedures (i.e. blood transfusion, dialysis, respirators) and exposure of newborns to different medical equipment in NICU can be an important risk factor for TDS and other reproductive disorders in later life $(28,29,33)$.

The environmental release of plasticizers is unpreventable since they are not covalently bound to the plastic materials (34). Phthalates have been suggested to have endocrine-disrupting properties in several in vitro and in vivo studies. Most of these studies suggest that phthalates, and particularly di-(2-ethylhexyl)phthalate (DEHP), have anti-androgenic potential (35-39). Phthalates can particularly affect the developing male reproductive system. However, they are also suggested to affect female reproductive system as well. Moreover, these endocrine disruptors may cause developmental anomalies. They can also affect the neuroendocrine system and can be associated with different endocrine diseases and pathological conditions, like precocious puberty (PP), diabetes, gynecomastia, obesity and/or metabolic syndrome, asthma and autism (40-46). Phthalates are also suspected to be one of the underlying factors of the increase in the prevalence of TDS (47). 


\section{Biotransformation of phthalates}

Upon ingestion, lipases and esterases in the intestine and parenchyma are responsible for the biotransformation of phthalates to monoester metabolites (Figure 6). Although the main tendency of biotransformation is detoxification of substances, this is not the case with phthalate diesters, and more active mono-ester phthalates are produced by Phase I metabolism (48). For instance, in in vitro studies mono(2-ethylhexyl)phthalate (MEHP), which is the primary metabolite of di(2-ethylhexyl)phthalate (DEHP) produced higher cytotoxicity and oxidative stress compared to DEHP in different cell lines $(37,49,50)$. In vitro and in vivo biotransformation studies revealed that short-branched phthalates are mainly excreted as their urinary monoester phthalates. However, longbranched phthalate esters undergo further biotransformation processes. The Phase I biotransformation of phthalates are achieved through hydroxylation and oxidation. Later, the primary compound or the first or secondary oxidized metabolites undergo conjugation (by glucuronidation and by sulfation to a lesser extent) before they are excreted by the kidneys or intestine (48,51-53).

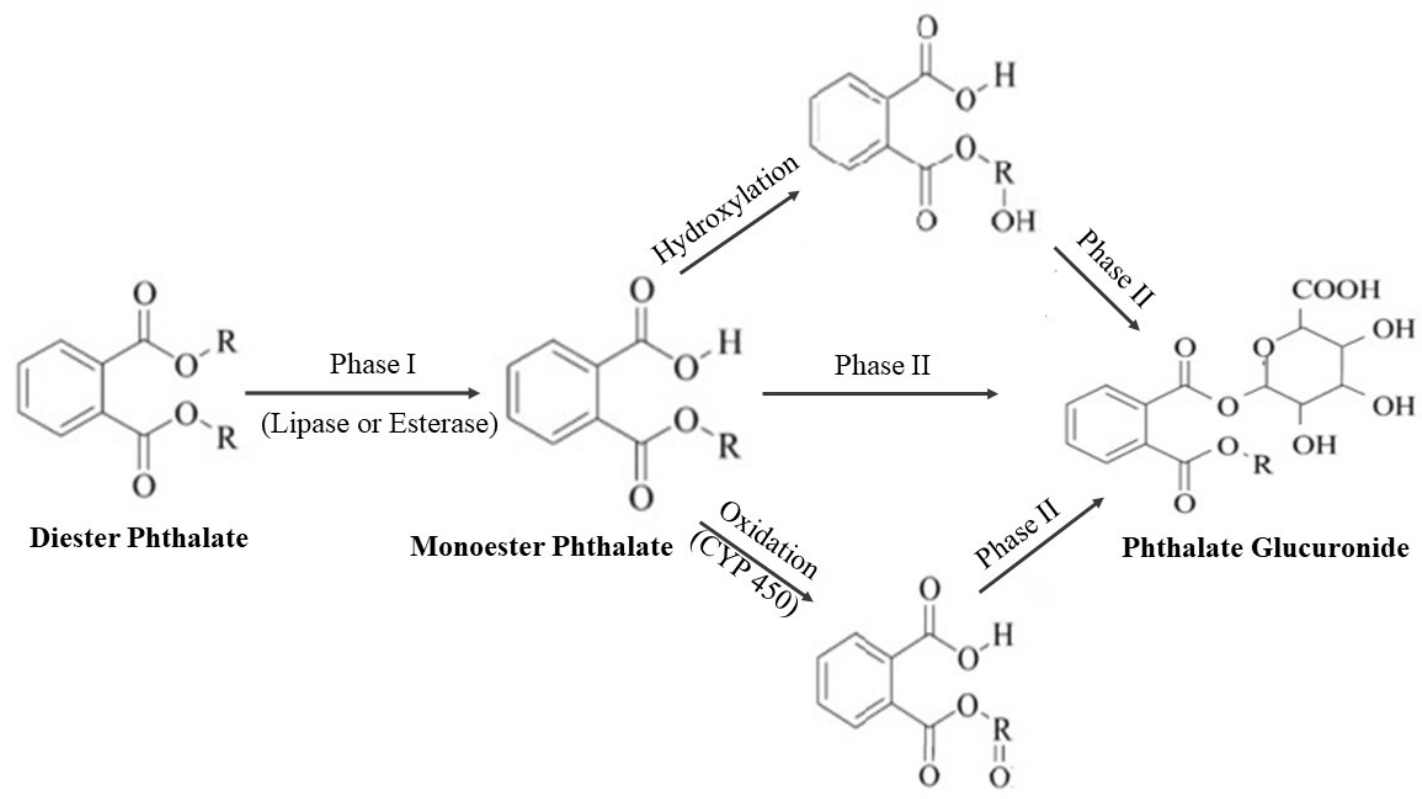

Figure 6. Biotransformation of phthalates

Slika 6. Biotransformacija ftalata 


\section{Different phthalate derivatives}

\section{Di(2-ethylhexyl)phthalate}

Plastics may contain $1 \%$ to $40 \%$ of DEHP. Almost three billion kilograms of DEHP is produced and used every year worldwide (54). DEHP is the diester of phthalic acid and the branched-chain 2-ethylhexanol. As DEHP is a very good and cheap plasticizer and fixator for color and smell, it is the most widely used phthalate in flexible PVC products and vinyl chloride resins $(28,29)$. It is also used as a hydraulic fluid and as a dielectric fluid in capacitors. DEHP also finds use as a solvent in glow sticks. DEHP is a component of many household items, including PVC windows, tablecloths, floor tiles, shower curtains, furniture upholstery, swimming pool liners and garden hoses. It may also be present in rainwear, dolls, toys and shoes. DEHP was first introduced in the 1940s to blood bags. This phthalate derivative is now present in medical devices like such as dialysis bags and tubing, intravenous tubing and bags, nasogastric tubes, IV catheters, blood bags and transfusion tubing, and air tubes (55). Due to high exposure of ICU and NICU patients, health concerns are now being expressed about the leachates of DEHP transported directly to the bloodstream of the patient, particularly in those who are in need of extensive infusions (56). Moreover, hemophiliacs and kidney dialysis patients are clearly at high risk $(55,57)$. According to the European Commission Scientific Committee on Health and Environmental Risks (SCHER), DEHP exposure may exceed the tolerable daily intake (TDI) in people exposed through medical procedures such as kidney dialysis. The exposure in NICU may increase the risk of developmental abnormalities in premature babies, newborns and neonates. On the other hand, lactating and pregnant women who are in need of medical interventions are at a great risk, as they can pass these chemicals directly to their babies (58). The use of DEHP-containing medical devices is not suggested by The American Academy of Pediatrics. The academy advocates for the use of DEHP-free medical devices (59).

DEHP is metabolized to its hydrolytic monoester MEHP by pancreatic lipases in the lumen of the gut after ingestion $(48,51,52)$. MEHP is further metabolized to oxidative metabolites in both rats, monkeys and humans (60-64). MEHP and its three major oxidative metabolites namely, mono(2-ethyl-5-oxohexyl) phthalate (MEOHP), mono(2ethyl-5-hydroxyhexyl) phthalate (MEHHP), and mono(2-ethyl-5-carboxypentyl) phthalate (MECPP), have been unequivocally identified in humans $(48,52,65)$. MEOHP and MEHHP are now suggested to be the potential DEHP exposure biomarkers (66). These metabolites can be glucuronidated before being excreted by the kidneys and intestine $(48,52,65,67)$. DEHP is classified as "possibly carcinogenic to humans" as there is sufficient evidence in animals for its carcinogenic potential (68).

\section{Diisononyl phthalate}

Diisononyl phthalate (DINP) is a phthalate derivative that is particularly present in food contact materials (69). DINP is also used in various types of plastic consumer products, including gloves, shoes, tubing, PVC flooring, materials used in automobile 
interiors, wire and cable insulation, as well as garden hoses. This phthalate is also present in some non-PVC products, such as some adhesives, paints, sealants, inks, pigments, and lacquers. DINP can be gradually released from consumer products into indoor environments. DINP can be detected on floors and other surfaces. DINP can accumulate in dust and air. DINP is on the Proposition 65 (the Safe Drinking Water and Toxic Enforcement Act of 1986) list. When California voters approved it by a 63-37\% majority, this proposition was passed as a law in November 1986. DINP was suggested to cause cancer in this proposition (70).

DINP is metabolized in the gastrointestinal tract by hydrolyzed to minor urinary metabolite monoisononyl phthalate (MiNP). MiNP is then oxidized in the liver to form secondary oxidative metabolites with hydroxyl, oxo and carboxyl functional groups [mono(carboxyisooctyl) phthalate (MCiOP), mono(oxoisononyl) phthalate (MOiNP), and mono(hydroxyisononyl) phthalate (MHiNP)] (71-73).

The maximum specific migration limit (SML) from food contact materials for DINP is set as $9 \mathrm{mg} / \mathrm{kg}$ (as the sum of diisononyl phthalates and diisodecyl phthalates) in the European Union (EU) (74).

\section{Diethyl phthalate}

Diethyl phthalate (DEP) is used as a plasticizer, fixative and solvent in several cosmetic formulations, including bath preparations (oils, soaps, tablets, and salts), make up products, fragrances, hair products, nail products and skin care preparations (75). More specifically, DEP is used in nail polish as a solvent for nitrocellulose and cellulose acetate (75-77).

Diethyl phthalate is also used as a plasticizer in different cellulose ester plastic films/sheets and also in molded/extruded articles. It is also present in tool handles, toys, toothbrushes and automotive components. There is a wide variety of consumer products that contain diethyl phthalate or are covered with diethyl phthalate-containing plastic packaging (75). In addition, this phthalate derivative is used in insecticide sprays and mosquito repellents. DEP is also as an ingredient in drug (e.g. aspirin) coatings, used as a plasticizer in solid rocket propellants, as a dye application agent, as a wetting agent, as a diluent in polysulfide dental impression materials, and in adhesives, plasticizers, and surface lubricants used in food and pharmaceutical packaging. In one study, the concentration of DEP in different medical devices (e.g. dialysis tubing) was found to be $<1 \%$ of total volatiles. However, in an intestinal tubing sample its concentration reached to $<20 \%$ of total volatiles ( 78 ).

There is little evidence on the chronic toxicity of this phthalate. Studies performed on rats suggested that repeated administration caused germ cell apoptosis in testicular tissue. However, DEHP did not affect male sexual differentiation in rats (71,79-81). The use of DBP in cosmetics (including nail polishes) is banned in EU under Directive 76/768/EEC 1976 (82). In EU, DBP has been restricted in children's toys since 1999 (83). 
In the lumen of the gastrointestinal tract or in the intestinal mucosal cells, it is hydrolyzed to its main metabolite, namely monoethyl phthalate (MEP) and ethanol by carboxyl esterase after oral exposure (83).

\section{Dibutyl phthalate}

Dibutyl phthalate (DBP) is a widely used phthalate derivative. The primary use for DBP is to soften and increase plastic flexibility. In elastomers, nail polish, lacquers, explosives and solid rocket propellants, DBP can be used as a plasticizer. Raincoats, food wraps, shower curtains and car interiors may also contain DBP. It may also be present in insect repellents and in perfume oil and resins as a solvent. Other uses include perfume fixative, textile lubricating agent, safety glass additive, printing inks, and adhesives. DBP is classified as a 'Group D' carcinogen by the EPA. The EPA stated that no definitive carcinogenic characteristics have been reported (84).

DBP is biotransformed to its main metabolite monobutyl phthalate (MBP) $(31,63)$. It can also be he glucuronidated in many organisms including humans, rats, hamsters and guinea pigs. It is also excreted as phthalic acid and unchanged compound. In addition, omega or omega-1 urinary oxidation products of MBP may be detected (84).

\section{Benzylbutyl phthalate}

Benzylbutyl phthalate (BBP) is mainly used as a plasticizer in PVC production. In vinyl foams, which are often used as floor tiles, BBP is commonly used as a plasticizer. It is also used in food packaging materials, conveyor belts, traffic cones and artificial leather (85).

BBP is metabolized to monoester metabolites by gut esterases. The major metabolites of BBP are monobutyl phthalate (MBP), mono-benzyl phthalate (MBzP) and mono-n-butyl phthalate monobenzyl phthalate (MnBP) to a lesser extent. The ratio of MBP to MBzP was found to be 5:3. These metabolites can be absorbed and excreted directly. They may also be subject to glucuronidation $(85,86)$.

It is suggested that $70 \%$ of BBP is not conjugated, while $30 \%$ is conjugated in rats. When BBP exposure is high, relatively less metabolite is conjugated. This suggests that the glucuronidation is saturated at high administrations. Its metabolites are rapidly excreted and $90 \%$ of these metabolites are eliminated within $24 \mathrm{~h}$. Therefore, the half-life of BBP in the blood is very low and it is only $10 \mathrm{~min}(86)$. However, monoester metabolites of BBP are shown to have a longer half-life $(\sim 6 \mathrm{~h})(87)$.

Until now, experimental research has not clearly identify the modes of action of $\mathrm{BBP}$ although it is known that this phthalate binds to the rat estrogen receptor (88). In vitro studies indicated the estrogenic potential of BBP. It has an effect on estrogenmediated gene expression. However, its metabolites are only weakly reactive with the estrogen receptor (89). 


\section{Diisobutyl phthalate}

Diisobutyl phthalate (DiBP) is another butyl phthalate derivative. DiBP is present in, for instance, floorings, in the production of titanium catalyzers, adhesives, coating products, fillers, putties, plasters, modelling clays, lacquers, inks, hydraulic fluids and lubricants. It has been used as marker in fuels for tax purposes (90). The results of several toxicological studies show that the male reproductive tract is a particularly sensitive target for effects after exposure to phthalates, including $\operatorname{DiBP}(91,92)$.

Its major metabolite is mono-isobutyl phthalate $(\mathrm{MiBP})(30,90)$. In humans, MiBP has a short halftime $(3.9 \mathrm{~h})$ while MiBP's oxidized further metabolites [3-OHmonoisobutyl phthalate (3-OH-MiBP) and 2- OH-monoisobutyl phthalate (2-OH-MiBP)] had longer half-lives (4.1 and $4.2 \mathrm{~h}$ ). These secondary oxidized metabolites can be used as additional and valuable biomarkers of DiBP exposure (93).

Phthalate derivatives and their uses are summarized in Table I.

Table I Phthalate derivatives and their uses.

Tabela I Derivati ftalata i njihove upotrebe

\begin{tabular}{|l|l|}
\hline Phthalate Derivative & Usage \\
\hline $\begin{array}{l}\text { Di(2-ethylhexyl)phthalate } \\
\text { (DEHP) }\end{array}$ & $\begin{array}{l}\text { PVC products and vinyl chloride resins, household items (PVC } \\
\text { Windows, tablecloths, floor tiles, shower curtains, furniture } \\
\text { upholstery, swimming pool liners and garden hoses), medical devices } \\
\text { (dialysis bags and tubing, intravenous tubing and bags, nasogastric } \\
\text { tubes, IV catheters, blood bags, transfusion tubing, and air tubes) }\end{array}$ \\
\hline Diisononyl phthalate (DINP) & $\begin{array}{l}\text { Plastic consumer products (PVC flooring, materials used in } \\
\text { automobile interiors, wire and cable insulation, gloves, tubing, garden } \\
\text { hoses and shoes), some inks and pigments, adhesives, sealants, paints } \\
\text { and lacquers. }\end{array}$ \\
\hline Diethyl phthalate (DEP) & $\begin{array}{l}\text { Bath preparations (oils, tablets, and salts), eye shadow, toilet waters, } \\
\text { perfumes and other fragrance preparations, hair sprays, wave sets, nail } \\
\text { polish and enamel removers, nail extenders, bath soaps, detergents, } \\
\text { aftershave lotions, and skin care preparations. }\end{array}$ \\
\hline Dibutyl phthalate (DBP) & $\begin{array}{l}\text { nitrocellulose lacquers, elastomers, explosives, nail polish, solid } \\
\text { rocket propellants, shower curtains, raincoats, food wraps, and car } \\
\text { interiors. }\end{array}$ \\
\hline Benzylbutyl phthalate (BBP) & $\begin{array}{l}\text { PVC production, vinyl foams, traffic cones, food conveyor belts, and } \\
\text { artificial leather. }\end{array}$ \\
\hline Diisobutyl phthalate (DiBP) & $\begin{array}{l}\text { Titanium catalyzers, adhesives, coating products, fillers, putties, } \\
\text { plasters, modelling clays, lacquers, inks, hydraulic fluids and } \\
\text { lubricants. }\end{array}$ \\
\hline
\end{tabular}




\section{Mechanisms for testicular dysgenesis syndrome caused by phthalates}

\section{Testis formation}

Testis formation is driven by the sex-determining region of the $\mathrm{Y}$ chromosome (SRY) activation, which leads to Sertoli cell differentiation (94). Formation of Sertoli cells later determines the fate of the indifferent gonad, directing its progression along testis development. Therefore, Sertoli cells are of particular importance for testicular development and they orchestrate dynamic processes such as cellular movement, cellular organization and differentiation of both themselves and all the other testicular cell types $(95,96)$.

On day 10 (E10), testis differentiates from the gonadal ridge primordium. Around the primordial germ cells, Sertoli cells form clusters and this phenomenon allow them to enclose germ cells within the seminiferous cords. One theory is that Sertoli cells signal the overlying mesonephros in order to allow cell migration into these cords and later further enabling cord development and expansion of the cell population (97). Eventually, seminiferous cords are surrounded by a basal lamina, which is formed by an interaction between Sertoli cells and peritubular myoid cells. Sertoli cells also induces Leydig cell differentiation is also induced by Sertoli cells (97). Leydig cells then produce testosterone, which is essential for the masculinization of the male reproductive tract. Müllerian duct regression in males is also induced by Sertoli cells by anti-Müllerian hormone (AMH). During testicular development, Sertoli cells secrete an unidentified inhibiting substance leads to the prevention of the germ cells to enter meiosis. This substance also blocks germ cells from entering the oogenic pathway. It is now known that many of genes as well as signaling pathways are involved in testis organogenesis. However, all of those genes/pathways are yet to be identified $(95,97)$.

Between embryogenesis and puberty, two separate generations of Leydig cells successively develop in the testis in rodents. The first are fetal Leydig cells, which differentiate from stem cells during gestation. Stem fetal Leydig cells commit and differentiate into mature fetal Leydig cells by E12. These cells are fully successful for steroidogenesis (98). Peak steroidogenic activity of fetal Leydig cells can be seen on 1 or 2 days prior to birth on gestation day 19 (99). The secretion of testosterone is crucial for male secondary sexual differentiation (i.e., the development of the penis and accessory sex glands) (98). Fetal Leydig cells also produce the protein-structured hormone insulinlike growth factor 3 (INSL3). This hormone binds to its specific receptor the leucine-rich repeat-containing G protein-coupled receptor 8 (LGR8) in the gubernaculum (100). INSL3 and testosterone both induce the scrotal descent of the testis (101). Research has shown that INSL3 is the critical hormone responsible for early stage descent of the testis from the abdominal to inguinal position. Studies show that mutations in humans result in the loss of function of INSL3 and in INSL3 knockout mice, this process is prevented (102). Therefore, it can be stated that any influence including hormone levels and environmental exposures on the development of fetal Leydig cells can lead to cryptorchidism. 
Fetal Leydig cells can remain in the testicular interstitial area after birth, although they quickly involute (103). After birth, their fate remains a subject of debate and there is no clear explanation in literature (104). However, research on the luteinizing hormone receptor null (LHRKO) mice stands behind the hypothesis that the cells are lost through attrition in the postnatal period. This point of view is backed by the fact that fetal Leydig cell count and their testosterone production are almost at the same level in null and wildtype mice just after birth, though a progressive failure of steroidogenesis is observed with the increasing age (105-107). This suggests that the fetal postnatal Leydig cell contribution to androgen secretion can be neglected. The cells that stem from adult Leydig cells first become apparent on PD11 as 3 $\beta$-hydroxysteroid dehydrogenase expressing spindle-shaped cells are observed in the interstitium (108). It has become evident that the process of postnatal development of adult Leydig cells includes: a. self-renewal of stem Leydig cells. b. their commitment to the adult lineage. c. further cytological and biochemical differentiation into fully differentiated and testosterone-producing adult Leydig cells (109). Several studies suggest that the exposures of fetal and adult Leydig cells to environmental chemicals, particularly to phthalates, may cause a wide array of testicular defects, including signs of TDS $(15,109,110)$.

Another important issue that should be discussed in the outcome of TDS are the effects on peritubular myoid cells and seminiferous cord formation. Peritubular myoid cells are positioned on the outer circumference of the seminiferous cord. These cells mainly serve as a visual boundary to separate the cords from the interstitium. The formation of the seminiferous cord has been described after in utero DBP administration to rats PD4, where abnormal seminiferous cord formation was observed. Such formation might lead to large and discrete areas in the testis with malformed cords, which contain Sertoli cells and gonocytes. These abnormal foci can become a permanent feature of the testis, which become more separate as the testis is enlarged during postnatal development (111). In human biopsies, malformed and morphologically abnormal seminiferous tubules were seen in the contra-lateral testis of testis cancer, suggesting this may also be a feature of TDS (98).

\section{Sex development disorders}

Although sex development disorders were rare in the 1960s and 1970s, they are observed at higher rates today. These pathologies were suggested to be caused by the hormonal disturbance of sexual determination and gonadal differentiation. In such conditions, there is a discrepancy between the phenotypic and the karyotypic sex of an individual and cases where classifying the phenotypic sex of an individual as male or female may be difficult. Sex development disorders that are mostly genetically determined (such as 45,X/46,XY mosaicism) and androgen insensitivity syndrome are considered to be among the risk factors most likely to be the leading causes of severe forms of TDS in humans (112-114). Starting from the end of the 1970s, several studies have verified that the prevalence of carcinoma in situ testis (CIS) and gonadal tumors is high in intersex patients with a karyotype including a Y chromosome (115-122). A special 
gonadal tumor named gonadoblastoma consists of nests of CIS-like cells and supportive cells resembling Sertoli/granulosa cells. This kind of tumors lead to gonadal neoplasia, arising almost exclusively in individuals with disorders of sex development. In phenotypic males, gonadoblastomas were linked to an increased risk of developing testicular cancer, whereas they were linked to dysgerminoma in phenotypic females (123125). However, CIS is not commonly seen in children with ambiguous genitalia in general, because the DSD is heterogeneous, and the increased risk of CIS is limited to individuals with the presence of $\mathrm{Y}$ chromosome material. In addition, patients with conditions associated with a lack of post-pubertal androgen stimulation (for instance, patients with the complete form of androgen insensitivity syndrome) or patients who have hypo-gonadotrophic hypogonadism rarely develop germ-cell neoplasia. This points out that androgen signaling may be one of the most important factors in the malignant transformation of pre-invasive CIS cells into overt tumors $(126,127)$.

Insulin-like 3 (INSL3) peptide is an insulin-like hormone in protein structure. It is encoded by the INSL3 gene in humans. In both genders, this peptide is mainly produced in gonadal tissues. Several rodent studies suggest that INSL3 can have roles in both urogenital tract development and female fertility. This hormone starts meiotic progression in follicle-enclosed oocytes by mediating a reduction in intra-oocyte cyclic adenosine monophosphate (cAMP) concentration by activating LGR8. It may also regulate the growth and differentiation of gubernaculum, thus mediating intra-abdominal testicular descent. The mutations in this gene may lead to cryptorchidism (128). Gene mutations in INSL3 and LGR8 are the first-described human genetic alterations specifically associated with cryptorchidism. The cumulative frequency of mutations in the INSL3 and LGR8 genes was determined to be $4.2 \%$ in a population of men with cryptorchidism. As these mutations represent a relatively small number of patients with cryptorchidism and there are different phenotypes observed in patients with the same mutation, endocrine and/or environmental factors are suggested to play important roles in the development of the phenotypes with cryptorchidism. Depending on the exposure time and dose, an environmental chemical can affect one, two or most of these processes and may cause a defect. Such defects may be one of the underlying factors of TDS (129).

\section{Testicular dysgenesis and phthalates}

For the last two decades, public awareness on the reproductive toxicity of different phthalate derivatives has been rising. In humans and rodents, phthalate exposure during testis development is associated with TDS, which is also called "phthalate syndrome". TDS has mainly endpoints, mostly associated with decreased testicular testosterone and INSL3 peptide levels. These endpoints are (93):

- Decreased fertility (associated with decreased sperm count and motility and increased abnormal sperm morphology)

- Decreased AGD

- Hypospadias

- Cryptorchidism

- Early-life testicular cancer 
Some of these endpoints - along with other health effects-have also been observed in epidemiologic studies (93). Some of the mechanisms by which in utero phthalate exposure cause TDS are (Figure 7) (130):

1. Direct effect on gonadal and non-gonadal tissues (including adrenals, brain, liver and adipose tissue).

2. Increase in estradiol levels due to alteration in aromatase activity.

3. Changes in testicular proteome.

4. Changes in homeostasis of interstitial fluid and/or vascular damage in the testis both of which leading to hemorrhage and consequent inflammatory changes.

5. Clustering of Leydig cells and decreased function:

a. Decreased INSL3 production which may lead to cryptorchidism;

b. Androgen insufficiency which causes decreased testosterone production, decrease in AGD and/or hyposphadias.

6. Disturbance in Sertoli cell functions:

a. Impaired spermatogenesis;

b. Testicular cancer.

7. Alterations in testosterone: estradiol ratio in testis.

8. Impairment of differentiation and morphogenesis of seminiferous tubules and accessory sex organs.

9. Epigenetic alterations.

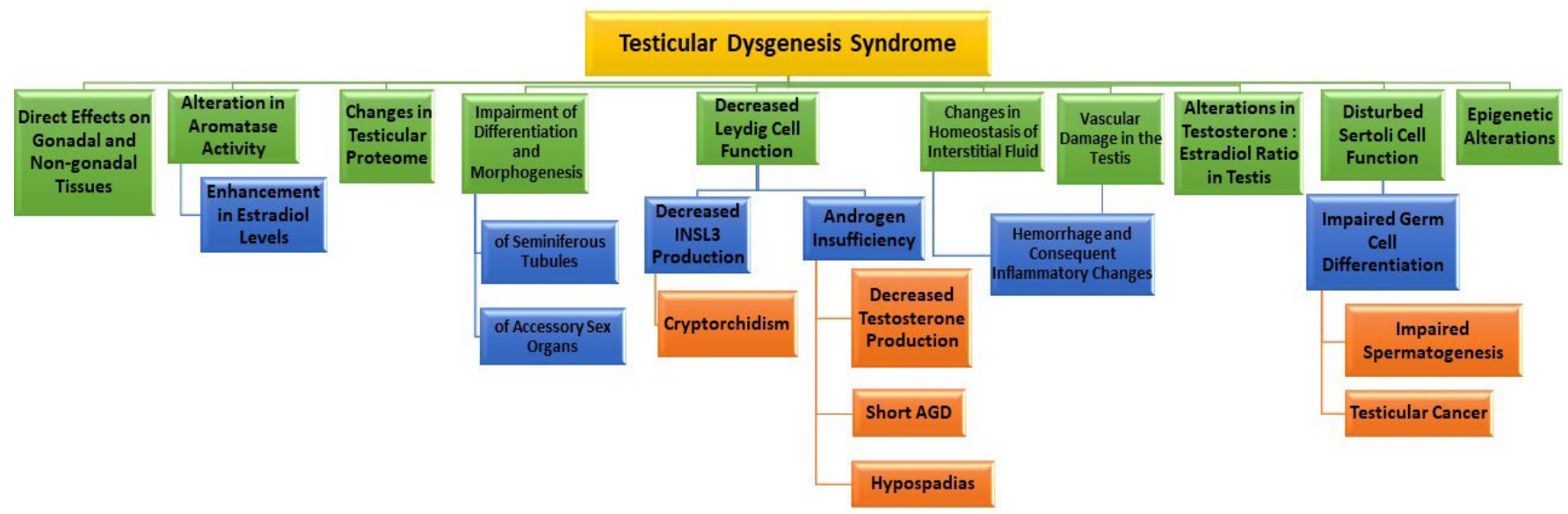

Figure 7. Mechanisms of testicular dysgenesis syndrome

Slika 7. Mehanizmi nastanka sindroma testikularne disgeneze 


\section{In vitro studies}

After the administration of DEHP during the co-culture of gonocytes and Sertoli cells, gonocytes showed detachment from the Sertoli cells. This phenomenon suggests problems with cell adhesion (131). In one study, primary Sertoli cells obtained from Sprague-Dawley rats were treated with 1,10 and $100 \mathrm{mg} / \mathrm{L} \mathrm{DBP}$. It was shown that DBP could significantly reduce the survival rate of Sertoli cells in a dose-dependent manner. Moreover, Hoechst staining results showed that the Sertoli cells treated with DBP emerged with typical morphological characteristics of apoptosis, nuclear condensation and chromatin condensation. In addition, DBP significantly increased the apoptotic rate of Sertoli cells dose-dependently. Moreover, showed that the expression of Phosphatase and tensin homolog (PTEN) * protein in Sertoli cells was markedly higher than control group after treated with different concentrations of DBP for $24 \mathrm{~h}$, while the expression of the proteins phosphorylated phosphatidylinositol-3-kinase (PI3K1), phosphorylated protein kinase B (AKT), phosphorylated P-70-S6 kinase (70S6K) and eukaryotic translation initiation factor 4E-binding protein 1 (4E-BP1) in the PI3K/AKT/mTOR signal pathway were significantly decreased. The authors suggested that PTEN/PI3K/AKT/mTOR signaling pathway played an important role in DBP-induced apoptosis of testicular Sertoli cells in rats (132).

\section{In vivo studies}

Starting from the 1990s, studies have focused on the gross changes caused by phthalates on male reproductive tract development, such as reduced AGD, hypospadias, malformed epididymis and, later on, nipple retention (133-137). In the 2000s, researchers started to investigate testicular histopathological changes observed in the testis after in utero phthalate exposure and observed that phthalates could directly affect the differentiation of fetal and neonatal testes $(111,137,138)$. Some of these changes could be permanent and lead to testicular dysfunction in adult life. These histological alterations are now known to be present in patients with TDS as well $(98,139)$.

There is now more in vivo evidence that is driven by the development of a possible animal model for TDS. It has been suggested that in utero phthalate administration during testicular development might cause changes in the function of Sertoli cells. DBP [500 $\mathrm{mg} / \mathrm{kg}$, on gestational days (GD) 13-21] was administered to rats by gavage as $500 \mathrm{mg} / \mathrm{kg}$ between gestational days (GD) 13-21. At GD19, an abnormal interaction between the Sertoli cells and gonocytes was reported in the fetus. Moreover, in postnatal testis examination, researchers observed evidence of abnormal Sertoli cell maturation, which was suggested to be caused by the lack of expression of the cell cycle marker p27kip in Sertoli cells in dysgenetic areas or Sertoli-cell-only tubules (SCO). In this study, abnormal seminiferous cord formation was also observed. The findings of this study suggested that in utero DBP exposure led to a lack of Sertoli cell-germ cell interaction/adhesion in rats and they developed cryptorchidism, hypospadias, infertility and testicular abnormalities (111). In the same year, another study showed that testicular development was disturbed after DBP was administered to pregnant rats by gavage at a 
dose of $500 \mathrm{mg} / \mathrm{kg}$ between embryonic day (E)13.5-20.5. In addition, prenatal fetal Leydig cell aggregation, which was proposed as a key event in the formation of the postnatally observed focal dysgenetic areas in the testis, was also observed (140). The results of these studies indicated that exposure to phthalates could be a cause of TDS-like symptoms. On the other hand, other agents, including a number of pesticides defined as environmental estrogens, may also have anti-androgenic properties (141).

Aside from the apparent cell adhesion problems between Sertoli cells and gonocytes and abnormal seminiferous cord formation after DBP or DEHP exposure, abnormal germ cell mitosis has also been reported $(81,111,137,138)$. In one report, DBP $(500 \mathrm{mg} / \mathrm{kg} /$ day $)$ or testosterone antagonist flutamide $(100 \mathrm{mg} / \mathrm{kg} / \mathrm{day})$ were given to pregnant rats on GD 12-21. DBP caused Leydig cell hyperplasia and many of the Leydig cells were $3 \beta-$ hydroxysteroid dehydrogenase- and/or AR-positive. Focal hyperplasia was characterized as the increases in the number of Leydig cells, positive for proliferating cell nuclear antigen (PCNA). Testis atrophy was apparent and seminiferous cords in DBP-exposed fetuses were enlarged and contained multinucleated gonocytes that, unlike controls, were PCNA-positive at GD 21. DBP, but not flutamide, markedly decreased testicular testosterone levels at GD 18 and 21. Fewer epididymal ducts and reduced AR staining in some ducts were evident with DBP treatment. In another study, maternal DEHP treatment $(750 \mathrm{mg} / \mathrm{kg} /$ day) from GD14 to postnatal day (PND) 3 led to a decrease in testosterone production and reduced testicular and whole-body testosterone levels in fetal and neonatal male rats from GD17 to PND2. As a consequence, AGD was reduced by $36 \%$ in the exposed male offspring on PND 2. However, no changes were seen in female offspring. By GD20, DEHP administration also led to significant decreases in testis weight. Histopathological findings showed that testes displayed enhanced $3 \beta$-hydroxysteroid dehydrogenase staining and increased numbers of multifocal areas of Leydig cell hyperplasia, as well as multinucleated gonocytes as compared to controls at GD 20 and PND 3 in the DEHP treatment group. In contrast to the effects of DEHP on testosterone levels in vivo, neither DEHP nor its metabolite MEHP displayed affinity for the human $\mathrm{AR}$ at concentrations of up to $10 \mu \mathrm{M}$ in vitro. These data indicate that DEHP disrupts male rat sexual differentiation by reducing testosterone to female levels in the fetal male rat during a critical stage of reproductive tract differentiation. In rodents, the appearance of multinucleated gonocytes (MNGs) was also observed in the fetal testes after phthalate exposure $(81,111,137,138)$.

Other than Sertoli cells, studies suggested that the number and distribution of fetal Leydig cells could be affected after rodents were exposed to altered DEHP or DBP in utero $(111,137,138)$. At around GD16, both focal hyperplasia within the interstitium and immuno-localization with the steroidogenic enzyme $3-\beta$ hydroxysteroid dehydrogenase of fetal Leydig cells was observed. In addition, when animals were examined in the postnatal period, Leydig cell hyperplasia was still present, especially near dysgenetic areas. Some of these areas were very large and they were classified as "Leydig cell adenomas" (133-135). 
Testosterone is the main factor in the normal masculinization of the male reproductive tract. The synthesis of testosterone by the fetal testis can first be at detectable levels on GD15. It reaches to a peak at around GD18/19. Testosterone levels remains high until birth. In different studies, both DEHP and DBP were shown to inhibit testosterone production $(60-85 \%)$ by the fetal testis during this critical developmental window, as indicated above. The decreased testosterone levels were almost at comparable levels with females of the same age. Testosterone inhibition may be a leading factor in the outcome of hypospadias and cryptorchidism $(111,137,138)$.

More recently, a study conducted by Li et al. (2015) investigated the association between in utero DINP exposure on fetal Leydig cell function and testis development. Female pregnant Sprague Dawley rats orally received different doses of DINP $(10,100$, 500 , and $1000 \mathrm{mg} / \mathrm{kg}$ ) from GD12 to GD21. Testosterone production in the testis, testicular gene and protein expression levels and fetal Leydig cell numbers and distribution were mainly at GD21.5. DINP led to a dose-dependent increase of fetal Leydig cell aggregation. The low observed adverse-effect level (LOAEL) was suggested to be $10 \mathrm{mg} / \mathrm{kg}$. For multinucleated gonocyte production, the LOAEL was found to be $100 \mathrm{mg} / \mathrm{kg}$. DINP also significantly increased fetal Leydig cell size, but inhibited INSL3 and $3 \beta$-hydroxysteroid dehydrogenase gene expression and protein levels at $10 \mathrm{mg} / \mathrm{kg}$ dose. At the highest dose, this particular phthalate caused the inhibition of testicular testosterone levels. Researchers suggested that in utero DINP exposure affected gonocyte multi-nucleation, some fetal Leydig cell steroidogenic gene expressions and caused the aggregation of Leydig cells (142).

Decreases in AGD have been shown to be one of the most sensitive endpoints for prenatal exposure to phthalates in male animals. As a longer AGD is suggested to be the masculinization of the external genitalia, its shortening can be interpreted as a subtle pattern of demasculinization or feminization (136).

Studies in the 2010s suggested a clear association between low sperm counts and motility in adult rats after DEHP exposure. DEHP was suggested to cause abnormal sperm production in rats and lead to disruption and collapse of vimentin filaments, as well as significantly induce the apoptotic death of germ cells $(37,143)$. A recent study aimed to evaluate the effects of single and combined exposures to BPA and/or DEHP in prenatal and lactational period on the male rat reproductive system in later stages of life. Pregnant Sprague-Dawley rats were randomly divided into four groups $(\mathrm{n}=3$ /group): DEHP was applied as $30 \mathrm{mg} / \mathrm{kg} /$ day, while BPA was applied as $50 \mathrm{mg} / \mathrm{kg} /$ day. In the combined exposure group, BPA+ DEHP were applied as $30 \mathrm{mg} / \mathrm{kg} /$ day DEHP and $50 \mathrm{mg} / \mathrm{kg} / \mathrm{day}$ BPA. Groups were orally exposed to BPA and/or DEHP through GD6-21 and lactation period. Male offspring ( $n=6 /$ group) from each mother were fed until adulthood. Later, reproductive hormones, sperm parameters, and oxidative stress parameters were determined. The researchers suggested prenatal and lactational exposure to BPA and DEHP may cause unwanted changes in the male reproductive system in later stages of life, while combined exposure seemed to have more pronounced effects (144). Moreover, another study also suggested that exposure to BPA and DEHP in fetal and neonatal 
periods could cause marked testicular histopathological alterations and lead to increases in testicular apoptosis markers (caspase 3 and caspase 8 level increases; increment in TUNEL-positive spermatogonia as well as TUNEL-positive testicular apoptotic cells) and autophagic proteins (as evidenced by increased LC3 and Beclin levels and decreased p62 levels). The researchers proposed that combined exposure to endocrine disrupting chemicals might lead to more significant changes in testicular structure and increase testicular cell death (145).

In a recent study, pregnant $C D$ rats $(n=10)$ were orally given $\operatorname{DBP}(0,250,500$, or $750 \mathrm{mg} / \mathrm{kg} /$ day) throughout pregnancy and lactation, until their offspring were at PND20. Although maternal body weights throughout the dosing period were not significantly different, the number of live pups per litter at birth was decreased and maternal effects on pregnancy and post-implantation loss were likely to have occurred at the highest dose group. AGD decreased at birth in the male offspring in both 500 and $750 \mathrm{mg} / \mathrm{kg} / \mathrm{day}-$ applied groups. The epididymis was absent or underdeveloped in 9,50 , and $71 \%$ of adult offspring (100 days old) at 250,500, and $750 \mathrm{mg} / \mathrm{kg} /$ day, respectively. This phenomenon was associated with testicular atrophy and widespread germ cell loss. Hypospadias occurred in 3,21, and $43 \%$ of males and ectopic or absent testes in 3, 6, and $29 \%$ of males at 250,500 , and $750 \mathrm{mg} / \mathrm{kg} /$ day, respectively. In both 500 and $750 \mathrm{mg} / \mathrm{kg} / \mathrm{day}-$ applied groups, the absence of the prostate gland and seminal vesicles, as well as small testes and seminal vesicles were also observed. Estrogen-dependent events, namely vaginal opening and estrous cyclicity, were not affected, although low incidences of reproductive tract malformations were observed at 500 and $750 \mathrm{mg} / \mathrm{kg} /$ day in the female offspring. DBP produced the same spectrum of effects elicited by the antiandrogen flutamide in the male offspring. The findings indicate that DBP specifically impaired the androgen-dependent development of the male reproductive tract. Therefore, the authors suggested that DBP is not only estrogenic, but anti-androgenic as well at higher dose levels (133). Another recent study on citrate substitutes (such as acetyl triethyl citrate-ATEC and acetyl tributyl citrate-ATBC) of DEHP investigated the anti-androgenic effects and cytotoxicity in castrated male Sprague-Dawley rats employing the in vivo Hershberger assay and in vitro mouse Leydig (TM3) cells and mouse fibroblast (NIH-3T3) cell lines. In the Hershberger assay, rats were administered testosterone propionate and ATEC or ATBC at 20, 100 or $500 \mathrm{mg} / \mathrm{kg}$ b.w./day or DEHP (500 mg/kg b.w./day). Positive controls received flutamide, negative controls received testosterone only and vehicle controls were given corn oil only. Both ATEC and ATBC administrations did not produce significant differences compared with testosterone in 5-androgen-dependent tissue weights, including the ventral prostate, seminal vesicles, levator ani-bulbocavernosus muscle, Cowper's glands, and glans penis. In the highest dose ATBC group, there were marked decreases in liver weight. Cytotoxicity tests showed that cell viabilities of both TM3 and NIH-3T3 cells treated with ATEC were not significantly altered. However, ATBC significantly reduced TM3 and NIH-3T3 cell viability in a concentration-dependent manner. Furthermore, ATBC reduced cell viability to a greater extent in TM3 versus NIH-3T3 cells. Concerning the alterations in reproductive tissue responses and cytotoxicity test results, the authors 
suggested that ATEC might be a better alternative to DEHP compared to ATBC for potential commercial uses (146).

As humans are exposed to different endocrine disruptors in mixtures in daily life, studies are now focusing on the toxic effects of different mixtures of these substances. The type of interaction between endocrine disruptors may be antagonistic or synergistic. In order to determine the real alterations in the metabolic, reproductive and endocrine systems, different in vivo models are used. The mode of action and biological activities of the mixtures are not well known today. Therefore, more studies are needed in order to make a reliable risk assessment. In a recent study, researchers were able to define interactions between different bisphenol derivatives (namely BPA, BPS, BPF, BADGE, BADGE $2 \mathrm{HCl}$ and phthalates (DEP, DBP) in ternary mixtures, at environmentally relevant concentration levels (BPA, BPF, BPS and BADGE $2 \mathrm{HCl}: 1.89,1.42,3.08$, and $0.326 \mu \mathrm{M}$, respectively) by employing bioluminescent bacteria (Microtox assay). The researchers unexpectedly observed a strong antagonistic impact with DEP, in mixtures containing BPA and BADGE analogues (also confirmed with mathematical models). This study also showed that the impact of BPS and BPF in many mixtures was highly concentration dependent, justifying the necessity of performing mixture studies using wide concentration ranges (147).

A study published in 2021 assessed the synergic, additive or antagonistic effects of oral co-exposure to BPA and DEHP in juvenile rats at environmentally relevant dose levels. Animals were grouped by applying low, middle and high doses of BPA $(2,6$, and $18 \mathrm{mg} / \mathrm{kg}$ b.w./day) and DEHP (9, 21, and $48 \mathrm{mg} / \mathrm{kg}$ b.w./day). The degree of synergism or antagonism was evaluated by synergy score calculation, using present data and results from the single compound individually administered. After certain calculations, the authors stated that co-exposure of BPA and DEHP mainly showed interactions of the antagonistic type (148).

In one recently conducted study, the link between DEHP, DBP and BPA coexposure and type 2 diabetes mellitus (T2DM), as well as the ability of multi-strained probiotic to reduce DEHP, DBP and BPA mixture-induced oxidative damage in rat pancreas were investigated. For data-mining, the Comparative Toxicogenomics Database, Cytoscape software and ToppGene Suite were used. Animals were sorted into seven groups $(n=6)$ and were sacrificed after 28 days: (1) Control group: corn oil, (2) P: probiotic: Saccharomyces boulardii + Lactobacillus rhamnosus + Lactobacillus plantarum LP 6595 + Lactobacillus plantarum HEAL9; (3) DEHP: 50 mg/kg b.w./day (oral), (4) DBP: $50 \mathrm{mg} / \mathrm{kg}$ b.w./day (oral), (5) BPA: $25 \mathrm{mg} / \mathrm{kg}$ b.w./day (oral), and (6) MIX: $50 \mathrm{mg} / \mathrm{kg}$ b.w./day DEHP $+50 \mathrm{mg} / \mathrm{kg}$ b.w/day DBP $+25 \mathrm{mg} / \mathrm{kg}$ b.w./day BPA (oral); (7) MIX + P (oral). In silico investigation highlighted 44 DEHP, DBP and BPA mutual genes linked to the T2DM, while apoptosis and oxidative stress were highlighted as the main mechanisms of DEHP, DBP and BPA mixture-linked T2DM. In vivo assessments confirmed the presence of significant changes in oxidative stress (total antioxidant capacity, superoxide dismutase and -SH groups) only in the MIX group, 
indicating possible additive effects, while probiotics ameliorated mixture-induced redox status changes in rat pancreatic tissue (149).

The A study conducted by Baralić et al. (2021) aimed to determine and compare the capacity of DEPH (50 mg/kg b.w./day), DBP (50 mg/kg b.w./day), BPA(25 mg/kg b.w./day) and their mixture (MIX: $50 \mathrm{mg} / \mathrm{kg}$ b.w./day DEHP+50 mg/kg b.w./day $\mathrm{DBP}+25 \mathrm{mg} / \mathrm{kg}$ b.w./day BPA) to produce testicular toxicity after subacute exposure (28 days) in male rats. The authors also explored the mechanisms behind the changes in the testis by using the in silico toxicogenomic approach. Histopathological investigations revealed that testicular toxicity observed in MIX group was more pronounced. Desquamated germinal epithelium cells, enlarged cells with hyperchromatic nuclei, multinucleated cell forms and intracytoplasmic vacuoles were observed more frequently when compared to DEHP or BPA groups. The alterations in the redox status parameters were either more prominent, or present only in the MIX group. In silico toxicogenomic analysis revealed that 20 genes linked to male reproductive disorders were altered both in individual exposure groups and in the MIX group. The effects on the metabolism, aryl hydrocarbon receptor (AhR) pathway, apoptosis and oxidative stress could be the most probable mechanisms involved in the subacute testicular toxicity of the mixture of DEHP+DBP+BPA (150).

The combined effects of in utero exposure to cadmium ( $\mathrm{Cd}, 0.25 \mathrm{mg} / \mathrm{kg} /$ once) and/or DBP $(250 \mathrm{mg} / \mathrm{kg} /$ day $)$ on fetal testis development in rats were investigated in an in vivo study performed on pregnant Sprague-Dawley rats. Cd and/or DBP were applied and the dams were randomly divided into four groups: control, Cd, DBP (250 mg/kg/day), and Cd + DBP. Cd was intraperitoneally injected to the dams on gestational day 12 and DBP was daily gavaged to the dams on gestational day 12 for 10 days. The researchers suggested that $\mathrm{Cd}, \mathrm{DBP}$, and $\mathrm{Cd}+\mathrm{DBP}$ lowered serum testosterone levels in male fetuses. However, Cd and DBP did not alter fetal Leydig cell (FLC) number, but the combined exposure led to a decreased FLC number. Cd did not affect FLC aggregation, while DBP caused FLC aggregation and the combined exposure worsened FLC aggregation. Cd lowered the FLC mRNA levels of certain genes (Lhcgr, Star, Cyp11a1, and Ins13) and DBP lowered the mRNA levels of Lhcgr, Star, Ins13, and Nr5a1. Cd and DBP and their mixture did not lead to decreases in Sertoli cell numbers and gene (Amh, Fshr, and Sox9) expressions. It was suggested that the combined exposure of $\mathrm{Cd}$ and $\mathrm{DBP}$ exerts antiandrogenic effects synergically via targeting FLC development (151).

\section{Human studies}

Among men, lower sperm concentration and motility have been reported after higher DnBP exposure in both infertility clinics (152-154) and the general population (155). A population-based study has suggested a weak relationship between maturation timing and urinary low molecular weight phthalates (e.g. DnBP and DiBP) and their monoester metabolites (156). Some studies also showed an increased risk of certain gynecological conditions when humans are exposed to high levels of DnBP $(157,158)$. Epidemiologic studies that have focused on neurodevelopment in infants $(159,160)$ and 
children (45,161-163) also suggest a link between neurodevelopmental disorders and phthalate exposure. On the other hand, Leydig cell hyperplasia ('micronodules') is common in testicular biopsies from men with impaired spermatogenesis and patients with testicular cancer, suggesting this is a feature of TDS $(98,164)$. An American study has examined this new endpoint in a group of 134 boys (2-30 months) and the urinary concentrations of 9 phthalate monoesters were correlated with the AGD. After adjusting for age, the researchers found a marked inverse correlation between AGD and 4 of phthalate metabolites (165). A recent study conducted on 100 umbilical cord blood samples analyzed the levels of bisphenol A (BPA), DEHP, MEHP and sex hormones. Male newborns were physically examined for AGD, stretched penile length (SPL), and penile width after birth. All endocrine disruptor levels were at detectable levels in $\sim 99 \%$ of cord blood samples. In covariate-adjusted models, cord blood BPA levels were inversely associated with the SPL of newborns and positively associated with cord blood estradiol levels. Moreover, a marked inverse relationship was present between DEHP levels and the AGD index. The results of this study suggested that in utero BPA and DEHP had significant effects on both fetal male reproductive development and cord blood estradiol levels (166).

\section{Conclusion}

It is impossible to avoid exposure to endocrine disruptors, as they are abundantly present in the environment. Phthalates are among the most common chemicals in the environment, and they affect and will continue to affect both human and environmental health negatively. Although exposure to phthalates is associated with many pathological conditions, TDS has been underestimated and overlooked. Today, the decline in fertility is a threat for future generations. Exposure to endocrine disruptors, especially different phthalate derivatives, is now recognized as one of the main causes of male fertility decline. Although some of the mechanisms by which phthalates cause TDS are understood, there are some mechanisms yet to be discovered. Scientists must clearly focus on these mechanisms through different in vitro and in vivo studies. Moreover, comprehensive epidemiological studies should be conducted, and the data of these studies should be well-evaluated in order to inform the society about the harmful effects of phthalates and their relationship with TDS.

Scientists must also suggest new regulations for phthalates. Due to the results of several studies on the toxic effects of phthalates, restriction proposal of four phthalates DEHP, BBP, DBP and DIBP in articles was prepared in 2016 by the European Chemicals Agency (ECHA) and Denmark. The assessment of the proposal by two ECHA Committees confirmed an inadequately controlled risk to human health from the exposure to four phthalates DEHP, BBP, DBP and DIBP in articles. The restriction proposal took into account the cumulative effects and combined exposure to these 4 phthalates from different articles. The restriction on placing articles containing the four phthalates in a concentration equal to or above $0.1 \%$ by weight individually or in any combination in any plasticized material on the market is set in a revised entry 51 of Annex XVII to the 
REACH Regulation (167). Turkey has also accepted that childcare supplies (like plastic parts of pencils and notebooks, erasers, connectors, scissors, sharpeners, rulers, parcels, tapes, sticky note pads, strips, liquid correctors, crayons, paint supplies, lunch bags, school bags, backpacks, painting bags), food imitation products, swimming aids, gym mats, sun beds, sea beds, plastic prints and accessories in textile design (raincoats, sports soles, plastic slippers) can only contain $0.1 \%$ phthalate by their weight (168).

In conclusion, we can suggest that new and less toxic alternatives to phthalates should be synthesized and used in the industry. The decrease in fertility and TDS will pose a significant problem in the near future, as the world's population is getting older and public health services will not be able to overcome this burden. New regulations should be implemented and governments should work together to build a greener and less toxic environment for future generations.

\section{References}

1. McLaughlin D. Fooling with Nature: Silent Spring Revisited. Frontline PBS 2010. [Internet] [cited 2021 Oct 10] Available from:

https://www.pbs.org/wgbh/pages/frontline/shows/nature/disrupt/sspring.html Last accessed: $12 / 21 / 2021$.

2. Glausiusz J. Better Planet: Can A Maligned Pesticide Save Lives? [Internet]. Discover Magazine; 2007 [cited 2021 Oct 10]. Available from: https://www.discovermagazine.com/environment/can-amaligned-pesticide-save-lives.

3. Paull J. The Rachel Carson Letters and the Making of Silent Spring. SAGE Journals. 2013;3(3):1-12.

4. US EPA. DDT-A Brief History and Status [Internet]. 2021 [cited 2021 Oct 10]. Available from: https://www.epa.gov/ingredients-used-pesticide-products/ddt-brief-history-and-status.

5. Lambert JQT. Rehabilitating Carson [Internet]. 2008 [cited 2021 Oct 10]. Available from: https://www.prospectmagazine.co.uk/magazine/rehabilitatingcarson.

6. International Programme On Chemical Safety DDT and its derivatives. Environmental Health Criteria monograph No. 009 [Internet]. 1979 [cited 2021 Oct 10]. Available from: https://inchem.org/documents/ehc/ehc/ehc009.htm.

7. Lammel G, Klánová J, Erić L, Ilić P, Kohoutek J, Kovacić I. Sources of organochlorine pesticides in air in an urban Mediterranean environment: volatilisation from soil. J Environ Monit. 2011;13(12):3358-64.

8. Report on Carcinogens. Dichlorodiphenyltrichloroethane [Internet]. National Toxicology Program, Department of Health and Human Services; 2014 [cited 2021 Oct 10]. Available from: https://ntp.niehs.nih.gov/ntp/roc/content/profiles/dichlorodiphenyltrichloroethane.pdf.

9. IARC Working Group on the Evaluation of Carcinogenic Risks to Humans . DDT, Lindane, and 2,4D. Lyon (FR): International Agency for Research on Cancer. (IARC Monographs on the Evaluation of Carcinogenic Risks to Humans, No. 113.) [Internet]. 2018; [cited 2021 Oct 10]. Available from: https://www.ncbi.nlm.nih.gov/books/NBK507424/ 
10. Kelce WR, Stone CR, Laws SC, Gray LE, Kemppainen JA, Wilson EM. Persistent DDT metabolite p,p'-DDE is a potent androgen receptor antagonist. Nature. 1995;375(6532):581-5.

11. Cohn BA, La Merrill M, Krigbaum NY, Yeh G, Park JS, Zimmermann L, et al. DDT Exposure in Utero and Breast Cancer. J Clin Endocrinol Metab. 2015;100(8):2865-72.

12. National Institute of Environmental Health Sciences [Internet]. Endocrine Disruptors; 2016 [cited 2021 Oct 10]. Available from:

https://web.archive.org/web/20160305203707/http://gewa.mpcer.nau.edu/files/endocrinedisruptors.pdf.

13. US EPA [Internet]. Research on Endocrine Disruptors; 2020 [cited 2021 Oct 10]. Available from: https://www.epa.gov/chemical-research/research-endocrine-disruptors.

14. WHO International Programme on Chemical Safety [Internet]. Global Assessment of the State-ofScience of Endocrine Disruptors; 2002 [cited 2021 Oct 10]. Available from: https://www.who.int/ipcs/publications/en/toc.pdf?ua=1.

15. Sharpe RM, Franks S. Environment, lifestyle and infertility an inter-generational issue. Nat Cell Biol. 2002;4 Suppl:s33-40.

16. Amaral Mendes JJ. The endocrine disrupters: a major medical challenge. Food Chem Toxicol. 2002;40(6):781-8.

17. Skakkebaek NE, Rajpert-De Meyts E, Main KM. Testicular dysgenesis syndrome: an increasingly common developmental disorder with environmental aspects. Hum Reprod. 2001;16(5):972-8.

18. Sharpe RM, Skakkebaek NE. Testicular dysgenesis syndrome: mechanistic insights and potential new downstream effects. Fertil Steril. 2008;89(2 Suppl):e33-8.

19. Erkekoglu, P, BelmaKoçer G. Testicular Dysgenesis Syndrome and Phthalates: Where do we Stand. J Genit Syst Disor. 2015;4:1.

20. Boisen KA, Kaleva M, Main KM, Virtanen HE, Haavisto AM, Schmidt IM, et al. Difference in prevalence of congenital cryptorchidism in infants between two Nordic countries. The Lancet. 2004;363(9417):1264-9.

21. Boisen KA, Chellakooty M, Schmidt IM, Kai CM, Damgaard IN, Suomi AM, et al. Hypospadias in a cohort of 1072 Danish newborn boys: prevalence and relationship to placental weight, anthropometrical measurements at birth, and reproductive hormone levels at three months of age. J Clin Endocrinol Metab. 2005;90(7):4041-6.

22. Richiardi L, Bellocco R, Adami H-O, Torrång A, Barlow L, Hakulinen T, et al. Testicular cancer incidence in eight northern European countries: secular and recent trends. Cancer Epidemiol Biomarkers Prev. 2004;13(12):2157-66.

23. Hemminki K, Li X. Cancer risks in Nordic immigrants and their offspring in Sweden. European journal of cancer. 2002;38(18):2428-34.

24. Howdeshell KL, Furr J, Lambright CR, Rider CV, Wilson VS, Gray Jr LE. Cumulative effects of dibutyl phthalate and diethylhexyl phthalate on male rat reproductive tract development: altered fetal steroid hormones and genes. Toxicol Sci. 2007;99(1):190-202.

25. Hutson JM, Williams M, Fallat ME, Attah A. Testicular descent: new insights into its hormonal control. Oxf Rev Reprod Biol. 1990;12:1-56. 
26. Rivas A, Fisher JS, McKinnell C, Atanassova N, Sharpe RM. Induction of reproductive tract developmental abnormalities in the male rat by lowering androgen production or action in combination with a low dose of diethylstilbestrol: evidence for importance of the androgen-estrogen balance. Endocrinology. 2002;143(12):4797-808.

27. Center of Disease Control an Prevention [Internet]. Phthalates Factsheet; 2021 [cited 2021 Oct 10]. Available from: https://www.cdc.gov/biomonitoring/Phthalates_FactSheet.html.

28. Agency for Toxic Substances and Disease Registry [Internet]. Toxicological Profile for Di(2ethylhexyl)phthalate. Atlanta, GA.: Public Health Service, U.S. Department of Health and Human Services; 2019 [cited 2021 Oct 10]. Available from: https://www.atsdr.cdc.gov/toxprofiles/tp9.pdf.

29. US EPA [Internet]. Bis(2-ethylhexyl) phthalate (DEHP); 2016 [cited 2021 Oct 10]. Available from: https://www.epa.gov/sites/default/files/2016-09/documents/bis-2-ethylhexyl-phthalate.pdf.

30. Centers for Disease Control and Prevention Program [Internet]. Phthalates; 2009 [cited 2021 Oct 10]. Available from: https://www.cdc.gov/biomonitoring/pdf/pthalates_factsheet.pdf.

31. European Chemicals Bureau [Internet]. Dibuthyl Phthalate; 2004 [cited 2021 Oct 10]. Available from: https://echa.europa.eu/documents/10162/04f79b21-0b6d-4e67-91b9-0a70d4ea7500.

32. Kay VR, Chambers C, Foster WG. Reproductive and developmental effects of phthalate diesters in females. Crit Rev Toxicol. 2013;43(3):200-19.

33. Yalçin SS, Erdal İ, Çetinkaya S, Oğuz B. Urinary levels of phthalate esters and heavy metals in adolescents with thyroid colloid cysts. Int J Environ Health Res. 2021 Feb 8:1-14. doi: 10.1080/09603123.2021.1883554. Epub ahead of print.

34. Hauser R, Calafat A. Phthalates and human health. Occup Environ Med. 2005;62(11):806-18.

35. Balbuena P, Campbell Jr J, Clewell III HJ, Clewell RA. Evaluation of a predictive in vitro Leydig cell assay for anti-androgenicity of phthalate esters in the rat. Toxicol In Vitro. 2013;27(6):1711-8.

36. Christiansen S, Boberg J, Axelstad M, Dalgaard M, Vinggaard AM, Metzdorff SB, et al. Low-dose perinatal exposure to di (2-ethylhexyl) phthalate induces anti-androgenic effects in male rats. Reprod Toxicol. 2010;30(2):313-21.

37. Erkekoglu P, Zeybek ND, Giray B, Asan E, Arnaud J, Hincal F. Reproductive toxicity of di (2ethylhexyl) phthalate in selenium-supplemented and selenium-deficient rats. Drug Chem Toxicol. 2011;34(4):379-89.

38. Kortenkamp A, Faust M. Combined exposures to anti-androgenic chemicals: steps towards cumulative risk assessment. Int J Androl. 2010;33(2):463-74.

39. Svechnikov K, Svechnikova I, Söder O. Inhibitory effects of mono-ethylhexyl phthalate on steroidogenesis in immature and adult rat Leydig cells in vitro. Reprod Toxicol. 2008;25(4):485-90.

40. Buluş AD, Aşci A, Erkekoglu P, Balci A, Andiran N, Koçer-Gümüşel B. The evaluation of possible role of endocrine disruptors in central and peripheral precocious puberty. Toxicol Mech Methods. 2016;26(7):493-500.

41. Dong RH, Zhang H, Zhang MR, Chen JS, Min W, Li SG, et al. Association between phthalate exposure and the use of plastic containers in Shanghai adults. Biomed Environ Sci. 2017;30(10):727-36.

42. Durmaz E, Aşçı A, Erkekoğlu P, Akçurin S, Gümüşel BK, Bircan İ. Urinary bisphenol a levels in girls with idiopathic central precocious puberty. J Clin Res Pediatr Endocrinol. 2014;6(1):16.

43. Durmaz E, Özmert EN, Erkekoğlu P, Giray B, Derman O, Hıncal F, et al. Plasma phthalate levels in pubertal gynecomastia. Pediatrics. 2010;125(1):e122-e9. 
44. Franken C, Lambrechts N, Govarts E, Koppen G, Den Hond E, Ooms D, et al. Phthalate-induced oxidative stress and association with asthma-related airway inflammation in adolescents. Int J Hyg Environ Health. 2017;220(2):468-77.

45. Kondolot M, Ozmert EN, Asc1 A, Erkekoglu P, Oztop DB, Gumus H, et al. Plasma phthalate and bisphenol a levels and oxidant-antioxidant status in autistic children. Environ Toxicol Pharmacol. 2016;43:149-58.

46. Stojanoska MM, Milosevic N, Milic N, Abenavoli L. The influence of phthalates and bisphenol A on the obesity development and glucose metabolism disorders. Endocrine. 2017;55(3):666-81.

47. Olesen IA, Sonne SB, Hoei-Hansen CE, Rajpert-DeMeyts E, Skakkebaek NE. Environment, testicular dysgenesis and carcinoma in situ testis. Review Best Pract Res Clin Endocrinol Metab. 2007;21(3):462-78.

48. Frederiksen H, Skakkebaek NE, Andersson AM. Metabolism of phthalates in humans. Mol Nutr Food Res. 2007;51(7):899-911.

49. Erkekoğlu P, Rachidi W, De Rosa V, Giray B, Favier A, Hincal F. Protective effect of selenium supplementation on the genotoxicity of di(2-ethylhexyl)phthalate and mono(2-ethylhexyl)phthalate treatment in LNCaP cells. Free Radic Biol Med. 2010;49(4):559-66.

50. Erkekoglu P, Rachidi W, Yuzugullu OG, Giray B, Favier A, Ozturk M, et al. Evaluation of cytotoxicity and oxidative DNA damaging effects of di(2-ethylhexyl)-phthalate (DEHP) and mono(2-ethylhexyl)-phthalate (MEHP) on MA-10 Leydig cells and protection by selenium. Toxicol Appl Pharmacol. 2010;248(1):52-62.

51. Heindel JJ, Powell CJ. Phthalate ester effects on rat Sertoli cell function in vitro: effects of phthalate side chain and age of animal. Toxicol Appl Pharmacol. 1992;115(1):116-23.

52. Koch HM, Bolt HM, Preuss R, Angerer J. New metabolites of di (2-ethylhexyl) phthalate (DEHP) in human urine and serum after single oral doses of deuterium-labelled DEHP. Arch Toxicol. 2005;79(7):367-76.

53. Rusyn I, Peters JM, Cunningham ML. Modes of action and species-specific effects of di-(2ethylhexyl) phthalate in the liver. Crit Rev Toxicol. 2006;36(5):459-79.

54. Lassen C, Maag J, Hubschmann LB, Hansen E, Searl A, Doust E, et al. Data on manufacture, import, export, uses and releases of Bis(2-ethylhexyl) phthalate (DEHP) as well as information on potential alternatives to its use. COWI, IOM \& Entec report to ECHA 2009.

55. Tickner JA, Schettler T, Guidotti T, McCally M, Rossi M. Health risks posed by use of Di-2ethylhexyl phthalate (DEHP) in PVC medical devices: A critical review. Am J Ind Med. 2001;39(1):100-11.

56. CJ FF, Palmero D, M'Madi F, Tolsa J. Phthalate exposure in the neonatal intensive care unit. Arch Pediatr. 2014;22(2):203-10.

57. Rock G, Labow RS, Tocchi M. Distribution of di (2-ethylhexyl) phthalate and products in blood and blood components. Environ Health Perspect. 1986;65:309-16.

58. Shelby MD. NTP-CERHR monograph on the potential human reproductive and developmental effects of di (2-ethylhexyl) phthalate (DEHP). NTP CERHR MON. 2006 Nov;(18):v, vii-7, II-iii-xiii passim. PMID: 19407857.

59. Shea KM, Health CoE. Pediatric exposure and potential toxicity of phthalate plasticizers. Pediatrics. 2003;111(6):1467-74. 
60. Albro PW, Hass JR, Peck CC, Odam DG, Corbett JT, Bailey FJ, et al. Identification of the metabolites of di-(2-ethylhexyl) phthalate in urine from the African green monkey. Drug Metab Dispos. 1981;9(3):223-5.

61. Albro PW, Lavenhar SR. Metabolism of di(2-ethylhexyl)phthalate. Drug Metab Rev. 1989;21(1):13-34.

62. Albro PW, Moore B. Identification of the metabolites of simple phthalate diesters in rat urine. J Chromatogr. 1974;94(0):209-18.

63. Kavlock R, Boekelheide K, Chapin R, Cunningham M, Faustman E, Foster P, et al. NTP center for the evaluation of risks to human reproduction: phthalates expert panel report on the reproductive and developmental toxicity of di (2-ethylhexyl) phthalate. Reprod Toxicol. 2002;16(5):529-653.

64. Koch HM, Bolt HM, Angerer J. Di (2-ethylhexyl) phthalate (DEHP) metabolites in human urine and serum after a single oral dose of deuterium-labelled DEHP. Arch Toxicol. 2004;78(3):123-30.

65. Preuss R, Koch HM, Angerer J. Biological monitoring of the five major metabolites of di-(2ethylhexyl) phthalate (DEHP) in human urine using column-switching liquid chromatographytandem mass spectrometry. J Chromatogr B Analyt Technol Biomed Life Sci. 2005;816(1-2):269-80.

66. Barr DB, Silva MJ, Kato K, Reidy JA, Malek NA, Hurtz D, et al. Assessing human exposure to phthalates using monoesters and their oxidized metabolites as biomarkers. Environ Health Perspect.2003;111(9):1148-51.

67. Silva MJ, Barr DB, Reidy JA, Kato K, Malek NA, Hodge CC, et al. Glucuronidation patterns of common urinary and serum monoester phthalate metabolites. Arch Toxicol. 2003;77(10):561-7.

68. IARC [Internet]. Di(2-ethylhexyl)phthalate; 2018 [cited 2021 Oct 10]. Available from: https://monographs.iarc.who.int/wp-content/uploads/2018/06/mono101-006.pdf.

69. European Comission [Internet]. Food Contact Materials; 2004 [cited 2021 Oct 10]. Available from: https://ec.europa.eu/food/safety/chemical-safety/food-contact-materials/legislation_en.

70. 65 P [Internet]. Safe Drinking Water and Toxic Enforcement Act of 1986; 1986 [cited 2021 Oct 10]. Available from: https://www.p65warnings.ca.gov/about/frequently-asked-questions.

71. Calafat AM, McKee RH. Integrating biomonitoring exposure data into the risk assessment process: phthalates [diethyl phthalate and di (2-ethylhexyl) phthalate] as a case study. Environ Health Perspect. 2006;114(11):1783-9.

72. Kato K, Silva MJ, Reidy JA, Hurtz D, 3rd, Malek NA, Needham LL, et al. Mono(2-ethyl-5hydroxyhexyl) phthalate and mono-(2-ethyl-5-oxohexyl) phthalate as biomarkers for human exposure assessment to di-(2-ethylhexyl) phthalate. Environ Health Perspect. 2004;112(3):327-30.

73. Silva MJ, Samandar E, Reidy JA, Hauser R, Needham LL, Calafat AM. Metabolite profiles of di-nbutyl phthalate in humans and rats. Environ Sci Technol. 2007;41(21):7576-80.

74. The EFSA Journal is a publication of the European Food Safety Authority [Internet]. Draft update of the risk assessment of di-butylphthalate (DBP), butyl-benzyl-phthalate (BBP), bis(2ethylhexyl)phthalate (DEHP), di-isononylphthalate (DINP) and di-isodecylphthalate (DIDP) for use in food contact materials; 2019 [cited 2021 Oct 10]. Available from: https://www.efsa.europa.eu/sites/default/files/consultation/consultation/Phthalates_in_plastic_FCM _draft_opinion_for_public_consultation.pdf.

75. Sekizawa, Jun, Dobson, Stuart, Touch, Ralph J, Sekizawa, Jun, Dobson, Stuart. et al. Diethyl phthalate. World Health Organization. 2003. 
76. Verschueren K. Handbook of Environmental Data on Organic Chemicals. Van Norstrand Reinhold Co. Inc: New York and Toronto. 1983. $1310 \mathrm{p}$.

77. Hawley GG, Lewis RJ. Condensed chemical dictionary: Wiley: New York. 2001. 1380 p.

78. Wahl HG, Hoffmann A, Häring H-U, Liebich HM. Identification of plasticizers in medical products by a combined direct thermodesorption-cooled injection system and gas chromatography-mass spectrometry. J Chromatogr A. 1999;847(1-2):1-7.

79. Foster PM, Thomas LV, Cook MW, Gangolli SD. Study of the testicular effects and changes in zinc excretion produced by some n-alkyl phthalates in the rat. oxicol Appl Pharmacol. 1980;54(3):392-8.

80. Foster P, Lake B, Thomas LV, Cook M, Gangolli S. Studies on the testicular effects and zinc excretion produced by various isomers of monobutyl-o-phthalate in the rat. Chem Biol Interact. 1981;34(2):233-8.

81. Gray Jr LE, Ostby J, Furr J, Price M, Veeramachaneni DR, Parks L. Perinatal exposure to the phthalates DEHP, BBP, and DINP, but not DEP, DMP, or DOTP, alters sexual differentiation of the male rat. Toxicol Sci. 2000;58(2):350-65.

82. The Council Of The European Communities [Internet]. Council Directive 76/768/EEC of 27 July 1976 on the approximation of the laws of the Member States relating to cosmetic products; 1976 [cited 2021 Oct 10]. Available from: https://eur-lex.europa.eu/LexUriServ/LexUriServ.do?uri=CELEX:31976L0768:EN:HTML

83. Api AM. Toxicological profile of diethyl phthalate: a vehicle for fragrance and cosmetic ingredients. Food Chem Toxicol. 2001;39(2):97-108.

84. Wallace DR. Dibutyl phthalate. Encyclopedia of Toxicology: Elsevier: The Netherlands. 2005. 2000 p.

85. Toft G, Jönsson BA, Lindh CH, Jensen TK, Hjollund NH, Vested A, et al. Association between pregnancy loss and urinary phthalate levels around the time of conception. Environ Health Perspect. 2012;120(3):458-63.

86. Mikuriya H, Ikemoto I, Tanaka A. Urinary metabolites contributing to testicular damage induced by butylbenzyl phthalate. Jikeikai Med J. 1988;35:403-9.

87. Eigenberg DA, Bozigian HP, Carter DE, Sipes IG. Distribution, excretion, and metabolism of butylbenzyl phthalate in the rat. J Toxicol Environ Health. 1986;17(4):445-56.

88. Zacharewski TR, Meek MD, Clemons JH, Wu Z, Fielden MR, Matthews JB. Examination of the in vitro and in vitro estrogenic activities of eight commercial phthalate esters. Toxicol Sci. 1998;46(2):282-93.

89. Picard K, Lhuguenot J-C, Lavier-Canivenc M-C, Chagnon M-C. Estrogenic activity and metabolism of n-butyl benzyl phthalate in vitro: identification of the active molecule (s). Toxicol Appl Pharmacol. 2001;172(2):108-18.

90. European Chemicals Agency [Internet]. Diisobutyl phthalate; 2017 [cited 2021 Oct 10]. Available from: https://echa.europa.eu/substance-information/-/substanceinfo/100.001.412.

91. Lyche JL, Gutleb AC, Bergman $\AA$, Eriksen GS, Murk AJ, Ropstad E, et al. Reproductive and developmental toxicity of phthalates. J Toxicol Environ Health B Crit Rev. 2009;12(4):225-49.

92. Lorber M, Koch HM. Development and application of simple pharmacokinetic models to study human exposure to di-n-butyl phthalate (DnBP) and diisobutyl phthalate (DiBP). Environ Int. 2013;59:469-77. 
93. Koch H, Christensen K, Harth V, Lorber M, Brüning T. Di-n-butyl phthalate (DnBP) and diisobutyl phthalate (DiBP) metabolism in a human volunteer after single oral doses. Arch Toxicol. 2012;86(12):1829-39.

94. Koopman P, Münsterberg A, Capel B, Vivian N, Lovell-Badge R. Expression of a candidate sexdetermining gene during mouse testis differentiation. Nature. 1990;348(6300):450-2.

95. Capel B. The battle of the sexes. Mech Dev. 2000;92(1):89-103.

96. Koopman P. Gonad development: signals for sex. Curr Biol. 2001;11(12):R481-R3.

97. Bullejos M, Bowles J, Koopman P. Searching for missing pieces of the sex-determination puzzle. J Exp Zool. 2001;290(5):517-22.

98. Hoei-Hansen CE, Holm M, Rajpert-De Meyts E, Skakkebaek NE. Histological evidence of testicular dysgenesis in contralateral biopsies from 218 patients with testicular germ cell cancer. J Pathol. 2003;200(3):370-4.

99. Nistal M, Gonzalez-Peramato P, Regadera J, Serrano A, Tarin V, De Miguel MP. Primary testicular lesions are associated with testicular germ cell tumors of adult men. Am J Surg Pathol. 2006;30(10):1260-8.

100. Ferrara D, Hallmark N, Scott H, Brown R, McKinnell C, Mahood IK, et al. Acute and long-term effects of in utero exposure of rats to di (n-butyl) phthalate on testicular germ cell development and proliferation. Endocrinology. 2006;147(11):5352-62.

101. Barlow NJ, Foster PM. Pathogenesis of male reproductive tract lesions from gestation through adulthood following in utero exposure to di (n-butyl) phthalate. Toxicol Pathol. 2003;31(4):397-410.

102. Kleymenova E, Swanson C, Boekelheide K, Gaido KW. Exposure in utero to di (n-butyl) phthalate alters the vimentin cytoskeleton of fetal rat Sertoli cells and disrupts Sertoli cell-gonocyte contact. Biol Reprod. 2005;73(3):482-90.

103. Codesal J, Regadera J, Nistal M, Regadera-Sejas J, Paniagua R. Involution of human fetal Leydig cells. An immunohistochemical, ultrastructural and quantitative study. J Anat. 1990;172:103.

104. Kerr JB. A light microscopic and morphometric analysis of the Sertoli cell during the spermatogenic cycle of the rat. Anat Embryol (Berl). 1988;177(4):341-8.

105. Zhang FP, Pakarainen T, Zhu F, Poutanen M, Huhtaniemi I. Molecular characterization of postnatal development of testicular steroidogenesis in luteinizing hormone receptor knockout mice. Endocrinology. 2004;145(3):1453-63.

106. Zhang FP, Poutanen M, Wilbertz J, Huhtaniemi I. Normal prenatal but arrested postnatal sexual development of luteinizing hormone receptor knockout (LuRKO) mice. Mol Endocrinol. 2001;15(1):172-83.

107. Lei Z, Mishra S, Zou W, Xu B, Foltz M, Li X, et al. Targeted disruption of luteinizing hormone/human chorionic gonadotropin receptor gene. Mol Endocrinol. 2001;15(1):184-200.

108. Ariyaratne HS, Mendis-Handagama SC, Hales DB, Mason JI. Studies on the Onset of Leydig Precursor Cell Differentiation in the Prepubertal Rat Testis1. Biol Reprod. 2000;63(1):165-71.

109. Ge R, Shan L, Hardy M. Pubertal development of Leydig cells. The Leydig Cell. AH Payne, MP Hardy, and LD Russell, editors. 1996;1:159-74.

110. Latini G, Del Vecchio A, Massaro M, Verrotti A, De Felice C. Phthalate exposure and male infertility. Toxicology. 2006;226(2-3):90-8. 
111. Fisher JS, Macpherson S, Marchetti N, Sharpe RM. Human 'testicular dysgenesis syndrome': a possible model using in-utero exposure of the rat to dibutyl phthalate. Hum Reprod. 2003;18(7):1383-94.

112. Aarskog D. Clinical and cytogenetic studies in hypospadias. Acta Paediatr Scand Suppl. 1970;203:Suppl 203:1+. PMID: 4319049

113. Scully R. Neoplasia associated with anomalous sexual development and abnormal sex chromosomes. Ped Adolesc Endocrinol. 1981;8:203-17.

114. Savage M, Lowe D. Gonadal neoplasia and abnormal sexual differentiation. Clin Endocrinol (Oxf). 1990;32(4):519-34.

115. Müller J, Skakkebaek NE. Testicular carcinoma in situ in children with the androgen insensitivity (testicular feminisation) syndrome. Br Med J (Clin Res Ed). 1984;288(6428):1419.

116. Müller J, Skakkebaek NE, Ritzén M, Plöen L, Petersen KE. Carcinoma in situ of the testis in children with 45, X/46, XY gonadal dysgenesis. J Pediatr. 1985;106(3):431-6.

117. Cassio A, Cacciari E, D'Errico A, Balsamo A, Grigioni FW, Pascucci MG, et al. Incidence of intratubular germ cell neoplasia in androgen insensitivity syndrome. Acta Endocrinol (Copenh). 1990;123(4):416-22.

118. Rutgers JL, Scully RE. The androgen insensitivity syndrome (testicular feminization): a clinicopathologic study of 43 cases. Int J Gynecol Pathol. 1991;10(2):126-44.

119. Ramani P, Yeung CK, Habeebu SS. Testicular intratubular germ cell neoplasia in children and adolescents with intersex. Am J Surg Pathol. 1993;17(11):1124-33.

120. Słowikowska-Hilczer J, Szarras-Czapnik M, Kula K. Testicular pathology in 46, XY dysgenetic male pseudohermaphroditism: an approach to pathogenesis of testis cancer. $\mathrm{J}$ Androl. 2001;22(5):781-92.

121. Słowikowska-Hilczer J, Romer TE, Kula K. Neoplastic potential of germ cells in relation to disturbances of gonadal organogenesis and changes in karyotype. J Androl. 2003;24(2):270-8.

122. Cools M, Drop SL, Wolffenbuttel KP, Oosterhuis JW, Looijenga LH. Germ cell tumors in the intersex gonad: old paths, new directions, moving frontiers. Endocr Rev. 2006;27(5):468-84.

123. Müller J, Visfeldt J, Philip J, Skakkebæk NE. Carcinoma in situ, gonadoblastoma, and early invasive neoplasia in a nine-year-old girl with 46, XY gonadal dysgenesis. APMIS. 1992;100(1-6):170-4.

124. Jørgensen N, Müller J, Jaubert F, Clausen OP, Skakkebaek NE. Heterogeneity of gonadoblastoma germ cells: similarities with immature germ cells, spermatogonia and testicular carcinoma in situ cells. Histopathology. 1997;30(2):177-86.

125. Cools M, Stoop H, Kersemaekers AMF, Drop SL, Wolffenbuttel KP, Bourguignon JP, et al. Gonadoblastoma arising in undifferentiated gonadal tissue within dysgenetic gonads. J Clin Endocrinol Metab. 2006;91(6):2404-13.

126. Hannema S, Scott I, Rajpert-De Meyts E, Skakkebaek N, Coleman N, Hughes I. Testicular development in the complete androgen insensitivity syndrome. J Pathol. 2006;208(4):518-27.

127. Rajpert-De Meyts E, Skakkebaek N. The possible role of sex hormones in the development of testicular cancer. Eur Urol. 1993;23:51-61.

128. Adham IM, Burkhardt E, Benahmed M, Engel W. Cloning of a cDNA for a novel insulin-like peptide of the testicular Leydig cells. J Biol Chem. 1993;268(35):26668-72. 
129. Ferlin A, Arredi B, Zuccarello D, Garolla A, Selice R, Foresta C. Paracrine and endocrine roles of insulin-like factor 3. J Endocrinol Invest. 2006;29(7):657-64.

130. Veeramachaneni DR, Klinefelter GR. Phthalate-induced pathology in the foetal testis involves more than decreased testosterone production. Reproduction. 2014;147(4):435-42.

131. Li L-H, Jester Jr WF, Orth JM. Effects of relatively low levels of mono-(2-ethylhexyl) phthalate on cocultured Sertoli cells and gonocytes from neonatal rats. Toxicol Appl Pharmacol. 1998;153(2):258-65.

132. Wang H, Wang J, Zhang J, Jin S, Li H. Role of PI3K/AKT/mTOR signaling pathway in DBPinduced apoptosis of testicular sertoli cells in vitro. Environ Toxicol Pharmacol. 2017;53:145-150.

133. Mylchreest E, Cattley RC, Foster PM. Male reproductive tract malformations in rats following gestational and lactational exposure to di (n-butyl) phthalate: an antiandrogenic mechanism? Toxicol Sci. 1998;43(1):47-60.

134. Mylchreest E, Sar M, Cattley RC, Foster PM. Disruption of androgen-regulated male reproductive development by di (n-butyl) phthalate during late gestation in rats is different from flutamide. Toxicol Appl Pharmacol. 1999;156(2):81-95.

135. Mylchreest E, Foster P. DBP exerts its antiandrogenic activity by indirectly interfering with androgen signaling pathways. Toxicol Appl Pharmacol. 2000;168(2):174-5.

136. Mylchreest E, Wallace DG, Cattley RC, Foster PM. Dose-dependent alterations in androgenregulated male reproductive development in rats exposed to di (n-butyl) phthalate during late gestation. Toxicol Sci. 2000;55(1):143-51.

137. Mylchreest E, Sar M, Wallace DG, Foster PM. Fetal testosterone insufficiency and abnormal proliferation of Leydig cells and gonocytes in rats exposed to di (n-butyl) phthalate. Reprod Toxicol. 2002;16(1):19-28.

138. Parks LG, Ostby JS, Lambright CR, Abbott BD, Klinefelter GR, Barlow NJ, et al. The plasticizer diethylhexyl phthalate induces malformations by decreasing fetal testosterone synthesis during sexual differentiation in the male rat. Toxicol Sci. 2000;58(2):339-49.

139. Skakkebaek NE, Holm M, Hoei-Hansen C, Jørgensen N, Rajpert-De Meyts E. Association between testicular dysgenesis syndrome (TDS) and testicular neoplasia: evidence from 20 adult patients with signs of maldevelopment of the testis. Apmis. 2003;111(1):1-9; discussion 9-11.

140. Mahood IK, Hallmark N, McKinnell C, Walker M, Fisher JS, Sharpe RM. Abnormal Leydig cell aggregation in the fetal testis of rats exposed to di (n-butyl) phthalate and its possible role in testicular dysgenesis. Endocrinology. 2005;146(2):613-23.

141. Sohoni P, Sumpter J. Several environmental oestrogens are also anti-androgens. J Endocrinol. 1998;158(3):327-40.

142. Li L, Bu T, Su H, Chen Z, Liang Y, Zhang G, et al. In utero exposure to diisononyl phthalate caused testicular dysgenesis of rat fetal testis. Toxicol Lett. 2015;232(2):466-74.

143. Erkekoglu P, Zeybek ND, Giray B, Asan E, Hincal F. The effects of di (2-ethylhexyl) phthalate exposure and selenium nutrition on sertoli cell vimentin structure and germ-cell apoptosis in rat testis. Arch Environ Contam Toxicol. 2012;62(3):539-47.

144. Balcı A, Özkemahlı G, Erkekoglu P, Zeybek D, Yersal N, Kocer-Gumusel B. Effects of prenatal and lactational bisphenol a and/or di (2-ethylhexyl) phthalate exposure on male reproductive system. Int J Environ Health Res. 2020:1-14. 
145. Balci A, Ozkemahli G, Erkekoglu P, Zeybek ND, Yersal N, Kocer-Gumusel B. Histopathologic, apoptotic and autophagic, effects of prenatal bisphenol A and/or di (2-ethylhexyl) phthalate exposure on prepubertal rat testis. Environ Sci Pollut Res Int. 2020;27(16):20104-16.

146. Sung CR, Kang HG, Hong JY, Kwack SJ. Citrate ester substitutes for di-2-ethylhexyl phthalate: In vivo reproductive and in vitro cytotoxicity assessments. J Toxicol Environ Health A. 2020;83(1718):589-595.

147. Jatkowska N, Kudłak B, Lewandowska P, Liu W, Williams MJ, Schiöth HB. Identification of synergistic and antagonistic actions of environmental pollutants: Bisphenols $\mathrm{A}, \mathrm{S}$ and $\mathrm{F}$ in the presence of DEP, DBP, BADGE and BADGE·2HCl in three component mixtures. Sci Total Environ. 2021;767:144286.

148. Tassinari R, Tait S, Busani L, Martinelli A, Valeri M, Gastaldelli A, et al. The Life Persuaded Project Group. Toxicological Assessment of Oral Co-Exposure to Bisphenol A (BPA) and Bis(2-ethylhexyl) Phthalate (DEHP) in Juvenile Rats at Environmentally Relevant Dose Levels: Evaluation of the Synergic, Additive or Antagonistic Effects. Int J Environ Res Public Health. 2021;18(9):4584.

149. Baralić K, Živančević K, Jorgovanović D, Javorac D, Radovanović J, Gojković T, et al. Probiotic reduced the impact of phthalates and bisphenol A mixture on type 2 diabetes mellitus development: Merging bioinformatics with in vivo analysis. Food Chem Toxicol. 2021;154:112325

150. Baralić K, Jorgovanović D, Živančević K, Buha Djordjević A, Antonijević Miljaković E, Miljković $\mathrm{M}$, et al. Combining in vivo pathohistological and redox status analysis with in silico toxicogenomic study to explore the phthalates and bisphenol A mixture-induced testicular toxicity. Chemosphere. 2021;267:129296.

151. Ma L, Mo J, Chen Y, Li L, Xie L, Chen X, et al. In utero cadmium and dibutyl phthalate combination exposure worsens the defects of fetal testis in rats. Environ Pollut. 2020;265(Pt A):114842.

152. Hauser R, Meeker JD, Duty S, Silva MJ, Calafat AM. Altered semen quality in relation to urinary concentrations of phthalate monoester and oxidative metabolites. Epidemiology. 7(6):682-91.

153. Pant N, Shukla M, Patel DK, Shukla Y, Mathur N, Gupta YK, et al. Correlation of phthalate exposures with semen quality. Toxicol Appl Pharmacol. 2008;231(1):112-6.

154. Pant N, Pant A, Shukla M, Mathur N, Gupta Y, Saxena D. Environmental and experimental exposure of phthalate esters: the toxicological consequence on human sperm. Hum Exp Toxicol. 2011;30(6):507-14.

155. Zhang Y-H, Zheng L-X, Chen B-H. Phthalate exposure and human semen quality in Shanghai: a cross-sectional study. Biomed Environ Sci. 2006;19(3):205-9.

156. Wolff MS, Teitelbaum SL, Pinney SM, Windham G, Liao L, Biro F, et al. Investigation of relationships between urinary biomarkers of phytoestrogens, phthalates, and phenols and pubertal stages in girls. Environ Health Perspect. 2010;118(7):1039-46.

157. Huang P-C, Tsai E-M, Li W-F, Liao P-C, Chung M-C, Wang Y-H, et al. Association between phthalate exposure and glutathione S-transferase M1 polymorphism in adenomyosis, leiomyoma and endometriosis. Hum Reprod. 2010;25(4):986-94.

158. Weuve J, Hauser R, Calafat AM, Missmer SA, Wise LA. Association of exposure to phthalates with endometriosis and uterine leiomyomata: findings from NHANES, 1999-2004. Environ Health Perspect. 2010;118(6):825-32. 
159. Kim Y, Ha EH, Kim EJ, Park H, Ha M, Kim JH, et al. Prenatal exposure to phthalates and infant development at 6 months: prospective Mothers and Children's Environmental Health (MOCEH) study. Environ Health Perspect. 2011;119(10):1495-500.

160. Whyatt RM, Liu X, Rauh VA, Calafat AM, Just AC, Hoepner L, et al. Maternal prenatal urinary phthalate metabolite concentrations and child mental, psychomotor, and behavioral development at 3 years of age. Environ Health Perspect. 2012;120(2):290-5.

161. Engel SM, Miodovnik A, Canfield RL, Zhu C, Silva MJ, Calafat AM, et al. Prenatal phthalate exposure is associated with childhood behavior and executive functioning. Environ Health Perspect. 2010;118(4):565-71.

162. Kim B-N, Cho S-C, Kim Y, Shin M-S, Yoo H-J, Kim J-W, et al. Phthalates exposure and attentiondeficit/hyperactivity disorder in school-age children. Biol Psychiatry. 2009;66(10):958-63.

163. Miodovnik A, Edwards A, Bellinger DC, Hauser R. Developmental neurotoxicity of ortho-phthalate diesters: review of human and experimental evidence. Neurotoxicology. 2014;41:112-22.

164. Holm M, Rajpert-De Meyts E, Andersson AM, Skakkebæk NE. Leydig cell micronodules are a common finding in testicular biopsies from men with impaired spermatogenesis and are associated with decreased testosterone/LH ratio. J Pathol. 2003;199(3):378-86.

165. Swan SH, Main KM, Liu F, Stewart SL, Kruse RL, Calafat AM, et al. Decrease in anogenital distance among male infants with prenatal phthalate exposure. Environ Health Perspect. 2005;113(8):1056-61.

166. Sunman B, Yurdakök K, Kocer-Gumusel B, Özyüncü Ö, Akbıyık F, Balcı A, et al. Prenatal bisphenol a and phthalate exposure are risk factors for male reproductive system development and cord blood sex hormone levels. Reprod Toxicol. 2019;87:146-55.

167. Eurpean Comission [Internet]. REACH Restrictions. Internal Market, Industry, Entrepreneurship and SMEs. [cited 2021 Dec 07]. Available from:

https://ec.europa.eu/growth/sectors/chemicals/reach/restrictions_en

168. Turkish Republic Ministry of Industry and Trade [Internet]. Hazardous Chemical Content Of Some Consumer Products Communiqué On Market Supervision And Audit [cited 2021 Dec 07]. Available from: https://www.resmigazete.gov.tr/eskiler/2011/04/20110402-9.htm 


\title{
Sindrom testikularne disgeneze $i$ izloženost ftalatima: Pregled literature
}

\author{
Pınar Erkekoglu ${ }^{1,2, *}$, Aylin Balcı Özyurt ${ }^{1}$, Anıl Yirün ${ }^{1,3}$, \\ Deniz Arca Çakır²
}

\author{
${ }^{1}$ Hacettepe University Faculty of Pharmacy \\ Department of Toxicology Sihhiye 06100 Ankara, Turkey \\ ${ }^{2}$ Hacettepe Vaccine Institute Department of Vaccine Technology \\ Sihhiye 06100 Ankara, Turkey \\ ${ }^{3}$ Çukurova Faculty of Pharmacy, Department of Toxicology Adana, Turkey
}

*Autor za korespondenciju: Pınar Erkekoglu, e-mail: erkekp@hacettepe.edu.tr

\begin{abstract}
Kratak sadržaj
Endokrini ometači su hemikalije koje ometaju rad endokrinog sistema i dovode do štetnih posledica u biološkim sistemima. Ftalati su grupa veštačkih hemikalija koje se uglavnom koriste kao plastifikatori i ubrajaju se u endokrine ometače. Takođe se upotrebljavaju kao fiksatori boje i mirisa u kozmetičkim proizvodima i proizvodima za ličnu negu. Pored toga, ftalati su pristuni u mastilima, lepkovima, zaptivačima, automobilskim delovima, alatima, igračkama, tepisima, medicinskim cevčicama i kesama za čuvanje krvi, kao i pakovanjima za hranu. Patološko stanje poznato kao „sindrom testikularne disgeneze“ (TDS) ili „ftalatni sindrom“ se obično dovodi u vezu sa izloženošću ftalatima. Ovaj termin je uveden kako bi se opisao porast promena u reproduktivnom zdravlju muškaraca, poput slabijeg kvaliteta semena (sniženi broj i pokretljivost spermatozoida, a povećan broj abnormalnih spermatozoida), hipospadije, kriptorhizma, smanjenja anogenitalne udaljenosti i raka testisa u ranoj životnoj dobi. Pretpostavlja se da ftalati izazivaju direktne posledice na gonadnim i negonadnim tkivima, ometaju diferencijaciju i morfogenezu seminifernih tubula i pomoćnih reproduktivnih organa i ćelija testisa (kako Sertolijevih, tako i Lejdigovih ćelija), dovode do promena u nivou estradiola i/ili testosterona, smanjuju proizvodnju insulinu-sličnih 3 (INSL3) peptida, narušavaju spermatogenezu i dovode do epigenetskih promena, što sve može prouzrokovati TDS. Ovaj pregled će se pretežno usredsrediti na ftalate kao uzročnike TDS i mehanizme njihovog delovanja.
\end{abstract}

Ključne reči: sindrom testikularne disgeneze, endokrini ometači, ftalat, poremećaji muškog reproduktivnog sistema 